\title{
Simulated warm polar currents during the middle Permian
}

\author{
A. M. E. Winguth, ${ }^{1}$ C. Heinze, ${ }^{2}$ J. E. Kutzbach, ${ }^{1}$ E. Maier-Reimer, ${ }^{2}$ U. Mikolajewicz, ${ }^{2}$ \\ D. Rowley, ${ }^{3}$ A. Rees, ${ }^{3}$ and A. M. Ziegler ${ }^{3}$
}

Received 9 April 2001; revised 12 April 2002; accepted 14 May 2002; published 17 October 2002.

[1] During Permian stage 6 (Wordian, Kazanian) the Pangaean supercontinent was surrounded by a superocean: Panthalassa. An ocean general circulation model has been coupled to an atmospheric energy balance model to simulate the sensitivity of the Wordian climate ( $\sim 265$ million years ago) to changes in greenhouse gas concentrations, high-latitude geography, and Earth orbital configurations. The model simulates significantly different circulation features with different levels of greenhouse gas forcing, ranging from a strong meridional overturning circulation in the Southern Hemisphere at low $\mathrm{CO}_{2}$ concentration (present level) to more symmetric overturning circulation cells with deep water formation in polar latitudes of both hemispheres at high $\mathrm{CO}_{2}$ concentration ( 8 times present level). The simulated climate with 4 times present level $\mathrm{CO}_{2}$ concentration agrees generally well with climate-sensitive sediments and phytogeographic patterns. The model simulates strong subtropical gyres with similarities to the modern South Pacific circulation and moderate surface temperatures on the southern continent Gondwana, resulting from a strong poleward heat transport in the ocean. An even more moderate climate is generated if high-latitude land is removed from the southern continent so that ocean currents can penetrate into the polar regions of Gondwana. INDEX TERMS: 3344 Meteorology and Atmospheric Dynamics: Paleoclimatology; 4267 Oceanography: General: Paleoceanography; 4532 Oceanography: Physical: General circulation; 4255 Oceanography: General: Numerical modeling; KEYWORDS: paleoceanography, Permian, paleoclimatology, general circulation

Citation: Winguth, A. M. E., C. Heinze, J. E. Kutzbach, E. Maier-Reimer, U. Mikolajewicz, D. Rowley, A. Rees, and A. M. Ziegler, Simulated warm polar currents during the middle Permian, Paleoceanography, 17(4), 1057, doi:10.1029/2001PA000646, 2002.

\section{Introduction}

[2] The long-term climate trend during the late Paleozoic era is documented in biogeographic provinces, climatesensitive sediments and organic productivity (e.g., coral reefs, evaporites, oil source rocks, coals, eolian sands, IRD, and glacial tillites) [Crowley and North, 1991; Ziegler et al., 1998]. These climate proxies indicate a significant climate transition from an "icehouse world" with extensive continental ice sheets during the Carboniferous $(\sim 330 \mathrm{Ma})$ to a generally ice-free state beginning in the Wordian (267 to $264 \mathrm{Ma})$. The greatest mass extinction in the Phanerozoic occurred at the Permo-Triassic boundary around $252 \mathrm{Ma}$, and several hypotheses have focused on the possible role of changes in the ocean, including a possible stratified ocean with an anoxic deep sea [Sepkoski, 1995; Isozaki, 1997]. The large Late Paleozoic-Early Mesozoic climate changes [Parish, 1998] were accompanied by large tectonic reorganization of the continents. The land-sea distribution during the Permian ( $\sim 290$ to 252 Ma years ago) was characterized by a supercontinent Pangaea with an almost closed meridional barrier [Seyfert and Sirkin, 1979; Ziegler et al., 1979], preventing a circumpolar current in contrast to the modern

\footnotetext{
${ }^{1}$ Center for Climatic Research, University of Wisconsin-Madison, Madison, Wisconsin, USA.

${ }^{2}$ Max-Planck-Institut für Meteorologie, Hamburg, Germany.

${ }^{3}$ Department of Geophysical Sciences, University of Chicago, Chicago, Illinois, USA.
}

Copyright 2002 by the American Geophysical Union. 0883-8305/02/2001PA000646\$12.00
[Mikolajewicz and Crowley, 1997]. In addition, incoming solar radiation was decreased compared to modern. Simulations with energy-balance climate models have demonstrated the importance of reduced solar radiation $(\sim 3 \%$ lower than the modern value) and low atmospheric $\mathrm{CO}_{2}$ concentration for the buildup of continental ice sheets during the Carboniferous and Early Permian [Crowley and Baum, 1992]. Several studies indicate that the retreat of the ice sheets during the Middle to Late Permian might be partially explained by an increased atmospheric $\mathrm{CO}_{2}$ concentration, from a value comparable to the modern level $\left(1 \times \mathrm{CO}_{2}\right)$ $\sim 300 \mathrm{Ma}$ to a quadrupled value $\left(4 \times \mathrm{CO}_{2}\right)$ around $265 \mathrm{Ma}$ [Crowley and Baum, 1992; Berner, 1994, 1997; Fawcett, 1994; Barron and Fawcett, 1995]. Comparison of the Wordian climate derived from floral and lithological data with simulations from the GENESIS 2 climate model indicate the fit is improved if the model is forced with $4 \times$ $\mathrm{CO}_{2}$ concentrations or higher rather than $1 \times \mathrm{CO}_{2}$ [Gibbs et al., 2002; Rees et al., 2002]. Variations of the Earth's orbital parameters could also significantly change the seasonal range in temperature at orbital timescales. Gibbs et al. [2002] showed that a combination of low $\mathrm{CO}_{2}$ levels (such as present-day levels) and a cold summer orbital configuration produces expanded areas of permanent snow cover.

[3] Ziegler [1998] suggested that the polar warming and a melting of the southern ice sheet in the Mid to Late Permian could have been triggered by a northward migration of Pangaea. Increased poleward heat transport of warm polar currents might have an important effect on the warming, and this has been documented by an ocean model simulation with idealized land-sea distribution [Kutzbach et al., 1990]. 
The importance of oceanic heat transport for a climate of a large supercontinent has also been discussed in previous climate studies for Paleozoic times. For example, ocean model simulations for the geographic configuration of the Late Ordovician ( 460-440 Ma) indicate an up to $\sim 42 \%$ increase in the poleward ocean heat transport in the Southern Hemisphere relative to present day [Poussard et al., 1999].

[4] The purpose of this study is to use climate models to explore the role of changed radiative forcing and changed land-ocean distribution on Wordian climate and ocean circulation. In particular we address the following questions: (1) What is the ocean circulation and oceanic heat transport for a middle Permian (Wordian) land/ocean distribution and idealized bathymetry in a dynamic ocean model? (2) How sensitive is the Wordian climate and ocean circulation to changes in the atmospheric $\mathrm{CO}_{2}$ concentration? (3) How does a change in land configuration near the southern pole influence the character of polar ocean currents, and how do these ocean currents affect the continental temperatures over Pangaea? (4) How well do the simulated continental and oceanic conditions agree with the geologic evidence? For this purpose, model simulations are compared with climate-sensitive sediments [Ziegler et al., 1998] and with phytogeographic patterns [Rees et al., 2002].

\section{Model Description}

\subsection{Coupled Model}

[5] The coupled model consists of two components, an atmospheric energy balance model and an ocean general circulation model (Figure 1). The use of an energy balance model for the atmosphere reduces significantly the computational costs and complexity in comparison to a fully coupled ocean-atmosphere general circulation model. The coupled atmospheric energy balance model (EBM) and large-scale geostrophic (LSG) ocean general circulation model, described in detail by Mikolajewicz [1996], has been applied to paleoclimatic studies [Mikolajewicz, 1996; Mikolajewicz and Crowley, 1997]. The nonlinear EBM is two-dimensional (longitude-latitude), having a single (well-mixed) vertical dimension, and is comparable to the model of North et al. [1983]. The atmosphere is dry and the only prognostic quantity is air temperature. The energy budget equation is solved with a time step of one day for surface air temperature $T_{\text {air }}$ and incorporates incoming solar radiation $F_{s w}$, outgoing long-wave radiation $F_{l w}$, and $\mathrm{CO}_{2}$ radiative forcing $F_{\mathrm{CO} 2}$ :

$$
\frac{\partial T_{\text {air }}}{\partial t}+\bar{U} \frac{\partial T_{\text {air }}}{\partial x}+A_{h} \nabla^{2} T_{\text {air }}=F_{s w}-F_{l w}+F_{C O 2}+\kappa \frac{\left(T_{o c}-T_{\text {air }}\right)}{c_{p} \rho_{\text {air }} H}
$$

The incoming solar radiation is either absorbed at the surface, reflected (surface albedo is a function of the ground temperature), or scattered/absorbed by prescribed clouds, ozone, and dust. The horizontal atmospheric transport in the EBM is parameterized as advection by the zonally averaged zonal component of the near-surface wind speed $(\bar{U})$ described by the second term on the left side of (1) and as diffusion described by the third term on the left side of (1). $A_{h}$ is the horizontal diffusion coefficient $\left(2.4 \times 10^{6} \mathrm{~m} \mathrm{~s}^{-1}\right)$, and $\nabla^{2}$ is the two-dimensional horizontal Laplace operator.

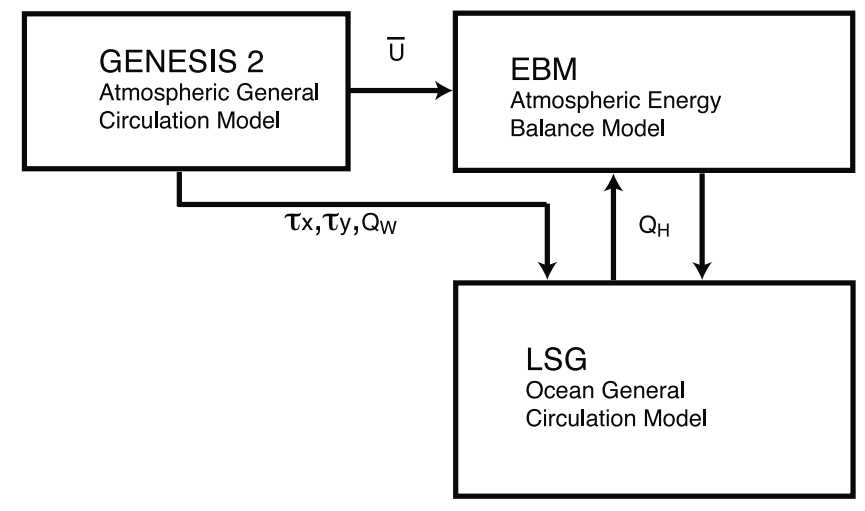

Figure 1. A model of intermediate complexity is used for this study described in section 2.1. The atmospheric component consists of an energy balance model (EBM). Change of local air temperature is given by equation (1) (see text) and determined by mean zonal advection, computed from the GENESIS 2 climate model [Thompson and Pollard, 1997], by horizontal diffusion, by incoming short-wave and outgoing long-wave radiation, and by sensible heat exchange with the surface $\mathrm{Q}_{\mathrm{H}}$. The oceanic component consists of an ocean general circulation model, the 22-layer version of the Hamburg LSG Mikolajewicz [1996] with a simple river runoff model to consider a mass balance of the hydrological cycle. The LSG is coupled to the EBM by surface heat flux $\mathrm{Q}_{\mathrm{H}}$ and forced by twodimensional fields of freshwater fluxes (precipitation minus evaporation and river runoff) $\mathrm{Q}_{\mathrm{w}}$ and wind stress $\left(\tau_{\mathrm{x}}, \tau_{\mathrm{y}}\right)$ computed from GENESIS 2 with the same boundary conditions (land/ocean distribution, $\mathrm{CO}_{2}$ radiative forcing, solar luminosity, and orbital parameters) as the EBM.

The surface wind speed is computed for the Wordian from a GENESIS 2 climate model [Thompson and Pollard, 1997] simulation (Figure 1) and for modern from the European Centre for Medium-Range Weather Forecasts (ECMWF) reanalysis 1979-1993. The heat fluxes between the EBM and ocean model are used to determine the distribution of temperature and sea ice in the mixed layer of the ocean, which is also integrated with a time step of one day. The resulting surface conditions serve as the lower boundary conditions for the atmosphere. The atmosphere-ocean heat exchange uses a coupling coefficient $\kappa$ of $40 \mathrm{~W} \mathrm{~m}^{-2} \mathrm{~K}^{-1}$ to simulate a strong damping for small-scale temperature changes and is reduced over areas of sea ice coverage. The conductive heat flux through sea ice is inversely proportional to the ice thickness and is proportional to the difference between the air temperature and the sea surface temperature $\left(T_{o c}\right)$ at air temperatures below freezing point. For the specific heat of dry air at constant pressure $c_{p}$, a constant value of $1004 \mathrm{~J} \mathrm{~K}^{-1} \mathrm{~kg}^{-1}$ is chosen. $\rho_{\text {air }}$ is the standard sea level density of the air, and $\mathrm{H}$ the atmospheric scale height $(\sim 7.6 \mathrm{~km})$. Over land (not shown in equation (1)) a surface energy balance equation predicts surface temperature with the assumption of zero heat capacity in soil.

[6] The Hamburg large-scale geostrophic ocean general circulation model (hereafter LSG) [Maier-Reimer et al., 1993; Mikolajewicz and Crowley, 1997] is coupled to the 
EBM via the surface heat exchange $\left(\mathrm{Q}_{\mathrm{H}}\right)$, the last term on the right hand side of equation (1), and is also forced by wind stress $\left(\tau_{\mathrm{x}}, \tau_{\mathrm{y}}\right)$ and freshwater flux $\left(\mathrm{Q}_{\mathrm{W}}\right)$ (precipitation minus evaporation plus river runoff; Figure 1) from $4 \times$ $\mathrm{CO}_{2}$ and $8 \times \mathrm{CO}_{2}$ Wordian simulations of Gibbs et al. [2002], which used the GENESIS 2 climate model [Thompson and Pollard, 1997]. In addition, two supplementary experiments, $1 \times \mathrm{CO}_{2}$ and $2 \times \mathrm{CO}_{2}$, with the same Wordian land configuration in GENESIS 2 have been used to provide additional prescribed values of $\tau_{\mathrm{x}}, \tau_{\mathrm{y}}, \bar{U}$, and $\mathrm{Q}_{\mathrm{W}}$ to explore the sensitivity to low atmospheric $\mathrm{CO}_{2}$ concentrations.

[7] The LSG uses a time step of 15 days, a spatial resolution of $3.5^{\circ} \times 3.5^{\circ}$ horizontally and 22 layers vertically, and allows computationally efficient long-term model integrations of several thousand years. The LSG uses twodimensional fields of heat fluxes $\left(\mathrm{Q}_{\mathrm{H}}\right)$, freshwater fluxes $\left(\mathrm{Q}_{\mathrm{w}}\right)$, and wind stress $\left(\tau_{\mathrm{x}}, \tau_{\mathrm{y}}\right.$; Figure 1$)$ to predict threedimensional fields of the ocean currents, potential temperature, salinity, tracers, and two-dimensional fields of sea level, and sea ice thickness. The LSG with 22 vertical layers includes an explicit formulation of vertical diffusion for temperature and salinity (diffusivity ranging from $5 \times$ $10^{-3} \mathrm{~m}^{2} \mathrm{~s}^{-1}$ at the surface to $2 \times 10^{-3} \mathrm{~m}^{2} \mathrm{~s}^{-1}$ for the intermediate and deep ocean), which is reduced in the case of very stable vertical stratification by a factor $\mathrm{a} /\left[\mathrm{a}+(\delta \rho / \delta \mathrm{z})^{2}\right]$ with $\mathrm{a}=4 \times 10^{-7} \mathrm{~kg}^{2} \mathrm{~m}^{-4}$. The selection of the diffusion scheme has been tested by various sensitivity experiments to reproduce the observed modern radiocarbon distribution in the ocean [Maier-Reimer et al., 1993; Mikolajewicz, 1996] and the deepening of the mid to high-latitude thermocline due to winter mixing. Results from these experiments indicated that the mixing of the deep sea significantly increases with an increase in the diffusion coefficients.

[8] The thermodynamic sea ice model from Maier-Reimer et al. [1993] has been modified to allow not only ocean driven transport of sea ice due to advection by the mean surface ocean currents predicted by the LSG, but also a wind-driven transport with an assumed equilibrium velocity proportional to the surface wind speed.

[9] A simple river runoff model with a bucket depth of 30 $\mathrm{cm}$ is used to transport the net precipitation from the land surface to the coastal ocean areas. The model is initialized for all Wordian experiments with a mean salinity of 34.3 and a mean temperature of about $4^{\circ} \mathrm{C}$ (world ocean's average mean temperature today). The reduction in salinity by 0.5 relative to the present-day value is based on the assumption that water stored in the form of ice, at modern times essentially in Antarctica and Greenland, was probably not present during the Wordian.

[10] Because the experimental design allows for forcing LSG with two-dimensional wind stress and freshwater flux from the companion GENESIS 2 Wordian simulations, this study is a considerable improvement over studies that use modern surface forcing for paleo experiments. However, there is still the important limitation that the wind stress and freshwater flux forcing is one-way, i.e. it does not allow for coupled interaction. Only the sensible heat exchange $\left(\mathrm{Q}_{\mathrm{H}}\right)$ is a two-way coupling (Figure 1). Fully coupled ocean-atmosphere paleoclimate simulations show important two-way interactions in polar regions [Schiller et al., 1997] and in the tropics [Shin, 2002]. We plan to test the effect of these limitations by studying feedback mechanisms between heat, fresh water, and momentum fluxes in future fully-coupled Permian climate simulations with a refined spatial and temporal resolution.

\subsection{Topography and Land-Sea Distribution}

[11] The paleogeographic basemaps for our simulations, including land-sea distribution, bathymetry and land surface elevation are taken from the Paleogeographic Atlas Project of the University of Chicago [Ziegler et al., 1997] (see http://pgap.uchicago.edu). Continental positioning is a crucial boundary condition for the atmospheric and oceanic circulation. The ocean circulation also depends on the mean depth of the ocean [Bice, 1997] and on the bathymetry, which is poorly known for the middle Permian. We assume therefore a flat bottom bathymetry with a depth of $4000 \mathrm{~m}$ based on the mean depth of the modern ocean. A smoothed transition from the continental shelves to the deep ocean is derived from the modern bathymetry (Figure 2a). The deep Tethys is cut off from the Panthalassa Ocean.

[12] The Permian paleogeography is reasonably well known, except for the position of islands in the Tethys Sea which belong nowadays to Southeast Asia. Rees et al. $[1999,2002]$ discussed the uncertainties of the positions of landmasses for these regions. The altitude of Pangaea mountain chains has a relevant impact on the climate simulations [Otto-Bliesner, 1993, 1998] and has been specified for the atmospheric model simulations [Gibbs et al., 2002]. The estimates of the orography are based on literature on geochronology, tectonics, sedimentary provinces, paleo-volcanism, and paleogeology. The Wordian continent in our baseline experiment is extended to the pole because of the coarse resolution model grid. Sensitivity experiments explore the effect of circumpolar currents in the Northern Hemisphere and in the Southern Hemisphere $\left(4 \times \mathrm{CO}_{2} \mathrm{~N}\right.$ and $4 \times \mathrm{CO}_{2} \mathrm{~S}$ ) when the land is removed between $70^{\circ}-90^{\circ}$ northern $(\mathrm{N})$ and southern (S) latitude (see section 3.3).

\subsection{Solar Luminosity and Orbital Parameters}

[13] The solar luminosity is thought to have been steadily increasing since formation, a consequence of conversion of hydrogen to helium. According to calculations by Boothroyd [see Caldeira and Kasting, 1992], we chose for the Wordian a reduction of $2.1 \%$ relative to the present-day solar constant of $1365 \mathrm{~W} \mathrm{~m}^{-2}$. Decreases of the Earth's rotation rate with time have been estimated from paleontological analysis [Scrutton, 1978] and tidal analysis [Williams et al., 1997]. However, changes from the Permian to present are smaller than 3\% and are neglected in the atmospheric and ocean model simulations.

[14] Previous studies [Crowley et al., 1992] indicate that orbital variations could be significant on a supercontinent. To study the sensitivity of the coupled model to orbital parameters we use the same three configurations as Gibbs et al. [2002]: For our reference run we assume the Earth's orbit about the sun was circular (eccentricity $=0$ ) and that the Earth's obliquity (axial tilt) was $23.5^{\circ}$. This setting causes an equal receipt of solar insolation for both hemispheres. Two additional extreme experiments with a hot and cold 
a) MODEL BATHYMETRY [km] (WORDIAN)

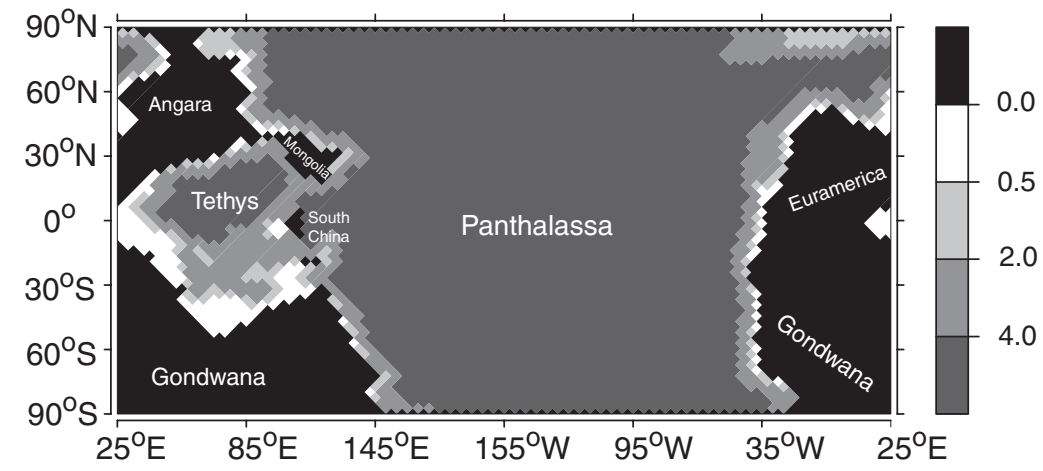

b) SEA SURFACE TEMPERATURE $\left[{ }^{\circ} \mathrm{C}\right]$ (WORDIAN 4XCO2)

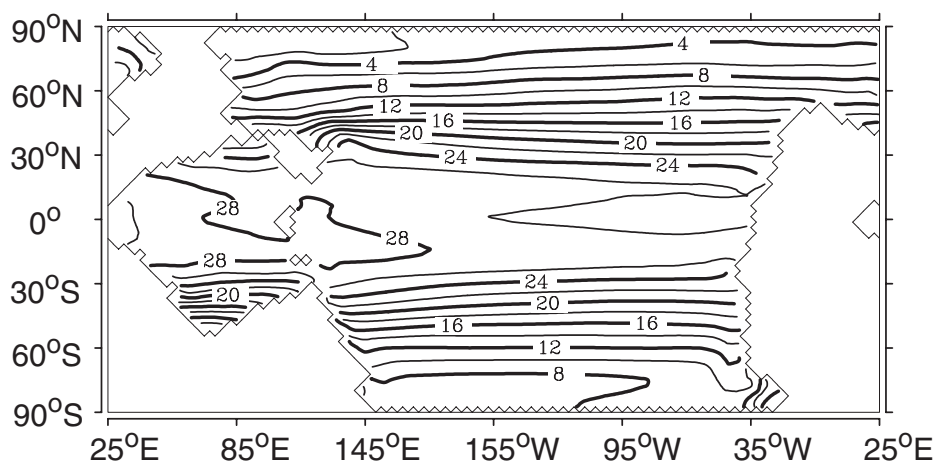

c) SURFACE AIR TEMPERATURE $\left[{ }^{\circ} \mathrm{C}\right]$ (WORDIAN 4XCO2)

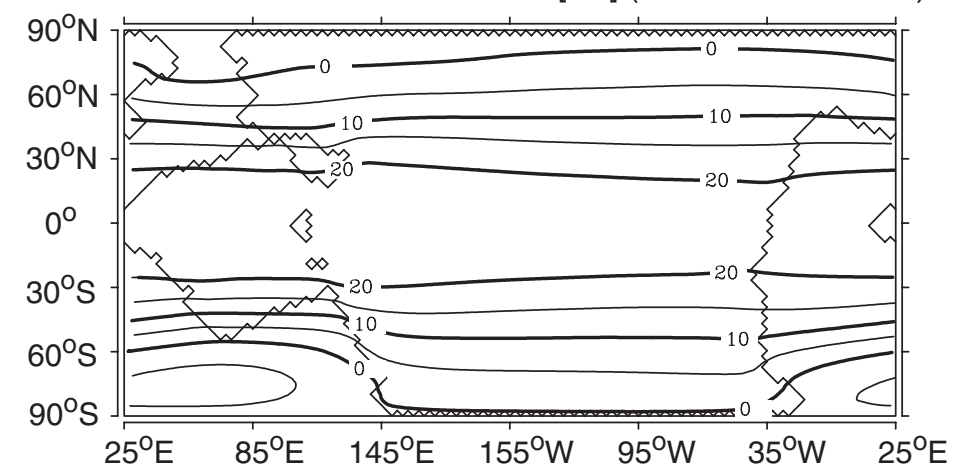

d) AIR-SEA HEAT FLUX [W $\left.\mathrm{m}^{-2}\right]$ (WORDIAN 4XCO2)

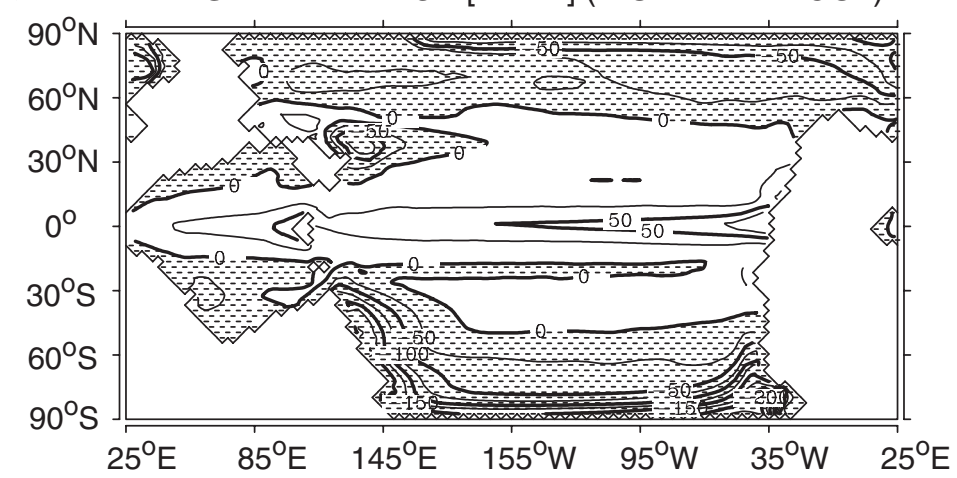

Figure 2. (a) Model bathymetry and (b) annual average of modeled sea surface temperature, (c) surface air temperature in ${ }^{\circ} \mathrm{C}$, and (d) air-to-sea heat flux in $\mathrm{W} \mathrm{m}^{-2}$ (stripple indicates flux to the atmosphere) for the Wordian climate with $4 \times \mathrm{CO}_{2}$ (contour interval for Figures $4 \mathrm{~b}-4 \mathrm{~d}$ is $2^{\circ} \mathrm{C}, 10^{\circ} \mathrm{C}$, and $25 \mathrm{~W} \mathrm{~m}^{-2}$, respectively). 
Table 1. Results From the Wordian Ocean Simulations ${ }^{\mathrm{a}}$

\begin{tabular}{|c|c|c|c|c|c|c|c|c|c|}
\hline Experiments & $\mathrm{T}_{\mathrm{o}},{ }^{\circ} \mathrm{C}$ & $\mathrm{SST},{ }^{\circ} \mathrm{C}$ & $\mathrm{SAT},{ }^{\circ} \mathrm{C}$ & $\mathrm{A}_{\text {ice }(\mathrm{NH})}, \%$ & $\mathrm{~A}_{\text {ice }(\mathrm{SH})}, \%$ & $\begin{array}{c}\mathrm{V}_{\text {ice }}, 10^{12} \\
\mathrm{~m}^{3}\end{array}$ & $\begin{array}{c}\mathrm{Q}_{\mathrm{TA}}, \mathrm{W} \\
\mathrm{m}^{-2}\end{array}$ & $\begin{array}{c}\mathrm{T}_{\mathrm{oc}} \text { at } 30^{\circ} \mathrm{S}, \\
\mathrm{PW}\end{array}$ & $\begin{array}{c}\mathrm{T}_{\mathrm{oc}} \text { at } 30^{\circ} \mathrm{N} \\
\mathrm{PW}\end{array}$ \\
\hline Present-day & 5.0 & 19.5 & 12.5 & 8.5 & 3.8 & 6.4 & 0.75 & -1.45 & 1.38 \\
\hline Wordian $4 \times \mathrm{CO}_{2}$ & 7.0 & 21.0 & 15.3 & 0.0 & 0.0 & 0.0 & 0.09 & -1.78 & 1.10 \\
\hline Wordian $1 \times \mathrm{CO}_{2}$ & 4.1 & 15.6 & 9.1 & 13.8 & 0.3 & 0.8 & 0.5 & -2.56 & 0.39 \\
\hline Wordian $2 \times \mathrm{CO}_{2}$ & 5.4 & 18.4 & 12.8 & 2.6 & 0.1 & 0.1 & 0.01 & -1.79 & 1.04 \\
\hline Wordian $8 \times \mathrm{CO}_{2}$ & 8.4 & 22.7 & 17.5 & 0.0 & 0.0 & 0.0 & 0.63 & -1.74 & 1.07 \\
\hline Wordian $4 \times \mathrm{CO}_{2} \mathrm{~N}$ & 6.7 & 20.7 & 15.2 & 0.0 & 0.0 & 0.0 & 0.33 & -1.90 & 0.89 \\
\hline Wordian $4 \times \mathrm{CO}_{2} \mathrm{~S}$ & 6.4 & 20.7 & 15.7 & 0.0 & 0.0 & 0.0 & 0.44 & -1.74 & 1.06 \\
\hline Wordian $4 \times \mathrm{CO}_{2} \mathrm{CSO}$ & 6.9 & 21.1 & 15.3 & 0.2 & 0.0 & 0.0 & 0.25 & -1.84 & 1.02 \\
\hline Wordian $4 \times \mathrm{CO}_{2} \mathrm{HSO}$ & 7.3 & 21.2 & 15.5 & 0.0 & 0.0 & 0.0 & 0.28 & -1.74 & 1.05 \\
\hline
\end{tabular}

${ }^{\mathrm{a}}$ Global and annual averages are used, unless otherwise noted. Climate simulations for the Wordian ocean are compared with the present-day experiment (preindustrial $\mathrm{CO}_{2}$ concentration of $280 \mathrm{ppm}$ ). The Wordian experiments in response to 4 times preindustrial $\mathrm{CO}_{2}$ concentration $\left(4 \times \mathrm{CO}_{2}\right)$ are defined to be the baseline experiment. Additional experiments investigate the change of the Wordian climate due to changes in the radiative greenhouse gas forcing $(1 \times$ $\mathrm{CO}_{2}, 2 \times \mathrm{CO}_{2}$, and $\left.8 \times \mathrm{CO}_{2}\right)$. Experiments with $4 \times \mathrm{CO}_{2}$ and northern circumpolar seaway $\left(4 \times \mathrm{CO}_{2} \mathrm{~N}\right)$ and southern circumpolar seaway $\left(4 \times \mathrm{CO}_{2} \mathrm{~S}\right)$ between $70^{\circ}$ and $90^{\circ}$ in northern and southern latitude explore the effect of circumpolar currents on the Wordian climate in high latitudes. The response of the Wordian climate to different orbital configurations (cold summer orbit CSO and hot summer orbit $\mathrm{HSO}$ ) is studied by using experiments $4 \times \mathrm{CO}_{2} \mathrm{CSO}$ and $4 \times \mathrm{CO}_{2} \mathrm{HSO}$. Annual averages are given for global mean temperature of the ocean $\mathrm{T}_{\mathrm{o}}$, mean sea surface temperature (SST), and mean surface air temperature (SAT). $\mathrm{A}_{\mathrm{ICE}}$ denotes the ratio of ice-covered area to total surface ocean area for the North Hemisphere (NH) and South Hemisphere (SH). $\mathrm{V}_{\text {ICE }}$ is the total ice volume in percent. $\mathrm{Q}_{\mathrm{TA}}$ denotes the net radiation for annual mean condition at the top of the atmosphere (see equation (2)), and $\mathrm{T}_{\mathrm{oc}}$ the poleward heat transport of the ocean at $30^{\circ} \mathrm{N}$ and $30^{\circ} \mathrm{S}$.

summer orbit were carried out. Similar to Crowley and Baum [1995], we use Berger's [1978] extreme values for the Pleistocene with an eccentricity of 0.06 for both experiments and an obliquity of $24.5^{\circ}$ for the warm summer orbit (WSO) and $22^{\circ}$ for the cold summer orbit (CSO).

\subsection{Atmospheric $\mathrm{CO}_{2}$ Level}

[15] The assumption of atmospheric $\mathrm{CO}_{2}$ level is crucial for the radiative forcing of the Earth's climate system. Here we use the functional form of greenhouse gas forcing from Wigley [1987] and a coefficient from Hansen et al. [1988] (consistent with the IPCC 1990 report) to define the changes in the net radiative flux at the tropopause (in $\mathrm{W} \mathrm{m}^{-2}$ ):

$$
\mathrm{F}_{\mathrm{CO} 2}=6.3 \ln \left(\mathrm{pCO}_{2} /\left(\mathrm{pCO}_{2}\right)_{\text {ref }}\right)
$$

with the preindustrial atmospheric partial pressure $\left(\mathrm{pCO}_{2}\right)_{\mathrm{ref}}=$ $280 \mathrm{ppmv}$. The radiative forcing due to a doubling of $\mathrm{CO}_{2}(2 \times$ $\mathrm{CO}_{2}$ ) is $4.4 \mathrm{~W} \mathrm{~m}^{-2}$ which is about $10 \%$ higher than the most recent IPCC2001 estimates of 3.5 to $4.1 \mathrm{~W} \mathrm{~m}^{-2}$ [Ramaswamy et al., 2001]. We are planning to use the improved estimates for future experiments and expect a slightly reduced sensitivity of the climate simulations due to $\mathrm{CO}_{2}$ radiative forcing. However, a small change in $\mathrm{CO}_{2}$ sensitivity is probably negligible compared to various other uncertainties in the reconstruction of the Permian climate. Concerning $\mathrm{CO}_{2}$ levels for the Wordian, Berner's [1994] GEOCARB II geochemical model results suggest a $\mathrm{CO}_{2}$ level near 4 times present $\left(4 \times \mathrm{CO}_{2}\right)$ for the Wordian, with a range of error estimates from about 1.5 to about 6 times present day. We conducted four experiments with $1,2,4$, and 8 times preindustrial $\mathrm{CO}_{2}$ levels to examine the sensitivity of the model climate to $\mathrm{CO}_{2}$.

\subsection{Land Surface}

[16] A uniform vegetation (mixed tree and grassland or savanna), Dorman and Sellers [1989], is imposed at every land grid point of the EBM and is consistent with the formulation of the land surface in the experiments carried out by the GENESIS 2 atmospheric model simulations
[Gibbs et al., 2002]. This prescribed land surface uniformity is clearly unrealistic; for instance a significant area of central Pangaea was probably desert. However, interpretations of results in comparison with observational evidence would be even more complicated if a nonuniform vegetation is assumed because of vegetation's significant effect on climate [e.g., Dutton and Baron, 1997; DeConto et al., 1999]. We are planning climate model experiments for the Permian that will include interactive vegetation based on the available data. Surface albedo over land is uniform for areas above the freezing point. In the EBM, snow cover with albedo of 0.85 is assumed for areas with temperatures below the freezing point. In the GENESIS 2 experiments, an explicit snow hydrology scheme predicts changes in surface albedo.

\section{Simulation Results}

\subsection{Wordian $4 \times \mathrm{CO}_{2}$ Baseline Experiment}

[17] The choice of $\mathrm{CO}_{2}$ for our baseline experiment was guided by Berner's [1994] geochemical cycle model which indicates that atmospheric $\mathrm{CO}_{2}$ rose from about present-day $\mathrm{CO}_{2}$ levels at about $300 \mathrm{Ma}$ to as high as about $4 \times \mathrm{CO}_{2}$ by the middle Permian. Our Wordian $4 \times \mathrm{CO}_{2}$ will be defined hereafter as the baseline experiment. We will discuss the model's response to lower levels of atmospheric $\mathrm{CO}_{2}$ concentration $\left(1 \times\right.$ and $\left.2 \times \mathrm{CO}_{2}\right)$ and to high levels of atmospheric $\mathrm{CO}_{2}$ concentration $\left(8 \times \mathrm{CO}_{2}\right)$ in section 3.2. The EBM/LSG baseline experiment is forced, as described in section 2 and Figure 1, with monthly climatologies of surface wind stress and precipitation minus evaporation of the final $5 \mathrm{yr}$ of the $20-\mathrm{yr}$ simulation of the WORD-4 $\times$ $\mathrm{CO}_{2}$ experiment [Gibbs et al., 2002] with the GENESIS 2 climate model.

[18] The simulated mean global average ocean temperature for the Wordian is $\sim 2^{\circ} \mathrm{C}$ higher than for the modern ocean simulation (Table 1). Ocean and land surface temperature (Figures 2b and 2c) indicate generally warmer conditions in high latitudes compared to modern. The moderate high-latitude sea surface temperatures (Figure 2b) are caused by the generally warmer "greenhouse" conditions 
WORDIAN (4XCO2) JANUARY

a) SEA SURFACE TEMPERATURE $\left[{ }^{\circ} \mathrm{C}\right]$

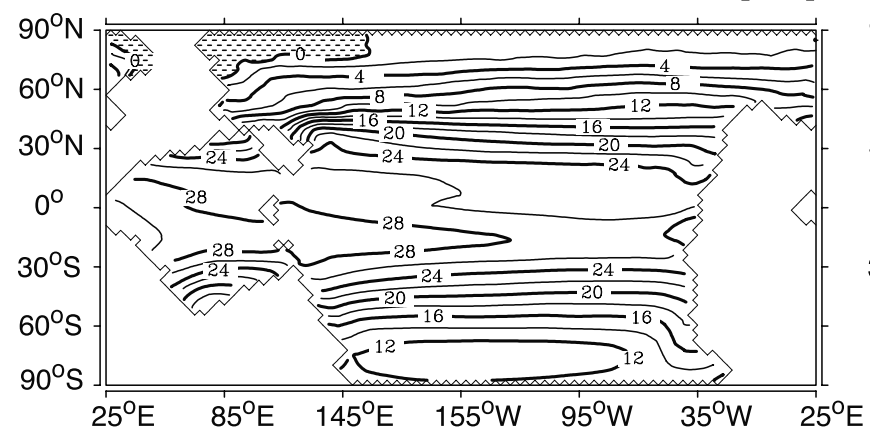

b) SURFACE AIR TEMPERATURE $\left[{ }^{\circ} \mathrm{C}\right]$

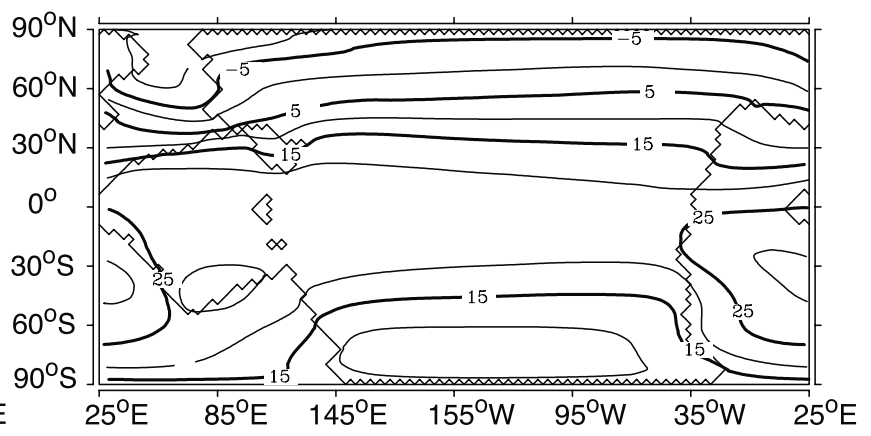

WORDIAN (4XCO2) JULY

c) SEA SURFACE TEMPERATURE $\left[{ }^{\circ} \mathrm{C}\right]$

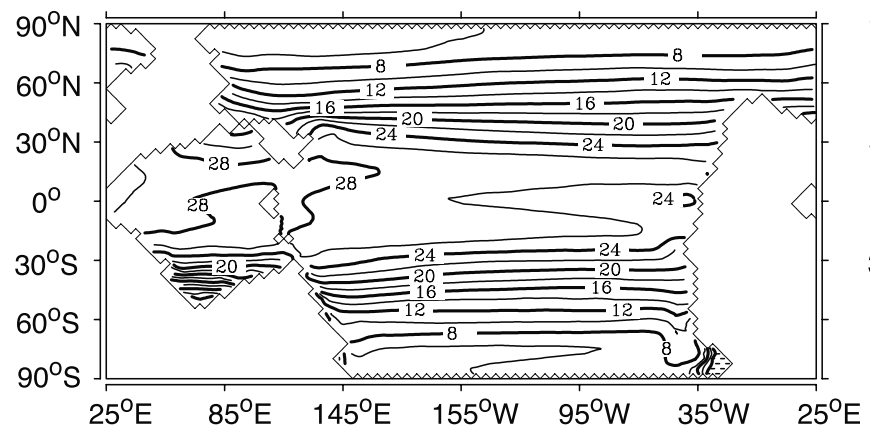

d) SURFACE AIR TEMPERATURE $\left[{ }^{\circ} \mathrm{C}\right]$

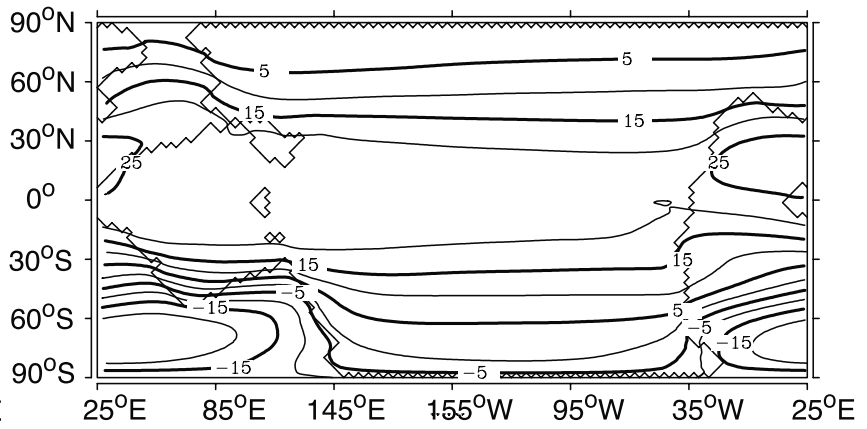

Figure 3. (left) January (Figure 3a) and July (Figure 3c) modeled sea surface temperature for the Wordian climate with $4 \times \mathrm{CO}_{2}$ (contour interval: $2^{\circ} \mathrm{C}$ ). (right) January (Figure 3b) and July (Figure $3 \mathrm{~d}$ ) air surface temperature for the $4 \times \mathrm{CO}_{2}$ experiment (contour interval: $5^{\circ} \mathrm{C}$ ).

$\left(4 \times \mathrm{CO}_{2}\right)$ and by significant heat flux from ocean to atmosphere (Figure 2d) reaching $150-200 \mathrm{~W} \mathrm{~m}^{-2}$ in the southern high latitudes. Lateral atmospheric heat transport, described in (1), with prevailing westerlies between $30^{\circ}$ and $60^{\circ}$ [Gibbs et al., 2002, Figure 9d] helps to warm the continents. The minimum temperatures of about $-20^{\circ} \mathrm{C}$ over South Gondwana (Figure 3) in the winter are about $10^{\circ}-15^{\circ} \mathrm{C}$ warmer than the minima simulated by Gibbs et al. [2002], and this warmer climate state can be related to a strong heat flux from ocean to atmosphere in the EBM/LSG model, although the atmospheric models are also different and no doubt contribute to the changes as well.

[19] The pattern of annual salinity (Figure 4) follows closely the prescribed P-E pattern [Gibbs et al., 2002, Figure 9d]. It shows the highest salinity in the eastern subtropical Panthalassa between $10^{\circ}$ and $30^{\circ}$ latitude, where most of the evaporation occurs. Minima in salinity are found just north of the equator at the mean position of the ITCZ and in high latitudes, where precipitation far exceeds evaporation. Differences in salinity of 1 unit between the southern Panthalassa and the Northern Hemisphere are related to a strong poleward current (Figure 5a) in the Southern Hemisphere and low freshwater input along the east coast of South Gondwana.
[20] Simulated east to west gradients of sea surface temperature in tropical Panthalassa are about $3^{\circ} \mathrm{C}$, with coldest water delivered by upwelling in the east and a warm pool in west extending into the Tethys Sea (comparable with the modern Pacific; Figure 5b). We note that the variability of the currents and upwelling is probably underestimated in the LSG because the numerical scheme filters out the fast

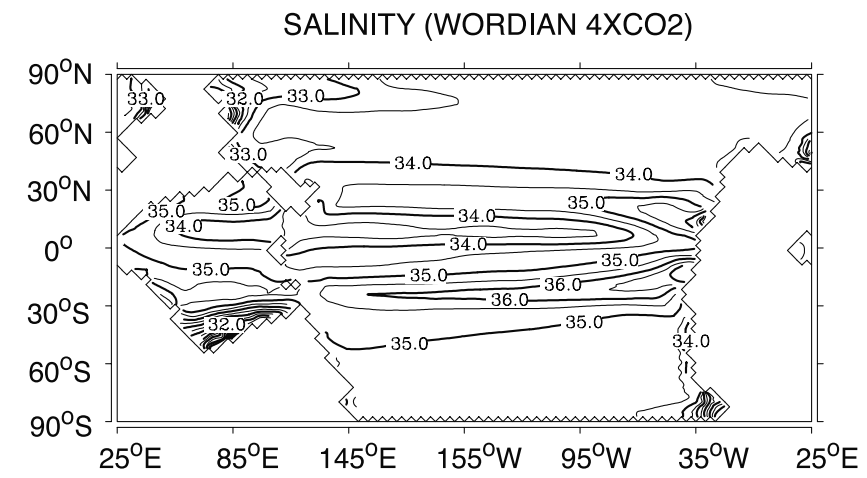

Figure 4. Annual average of surface salinity for the Wordian climate with $4 \times \mathrm{CO}_{2}$ (contour interval: 0.5 ). 
a) SURFACE HORIZONTAL VELOCITY [cm s-1] (WORDIAN 4XCO2)

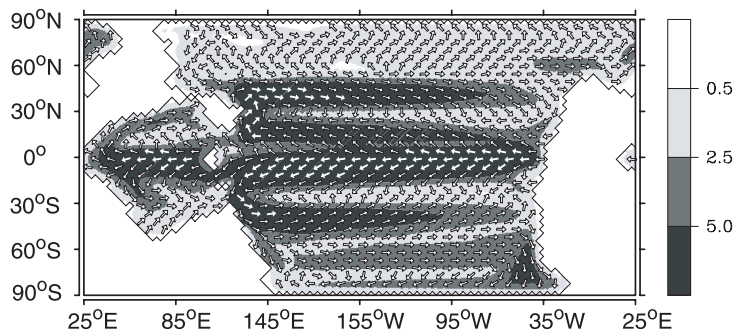

b) SURFACE VERTICAL VELOCITY [10-6 $\mathrm{m} \mathrm{s}^{-1}$ (WORDIAN 4XCO2)

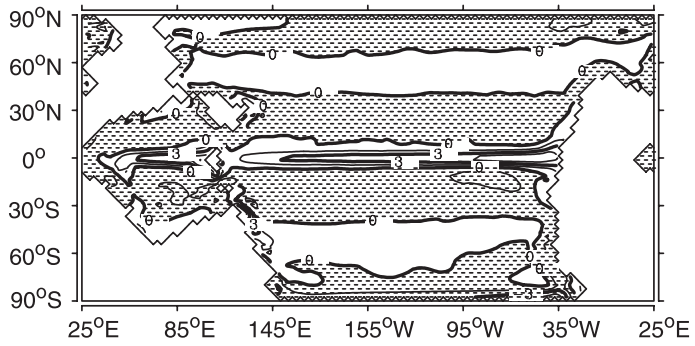

c) STREAMFUNCTION $\left[10^{6} \mathrm{~m}^{3} \mathrm{~s}^{-1}\right]$ (WORDIAN 4XCO2)

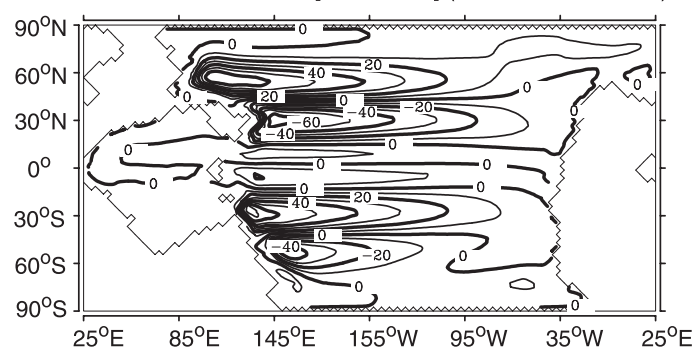

d) POT. ENERGY LOSS BY CONVECTION [mW m-2] (WORDIAN 4XCO2)

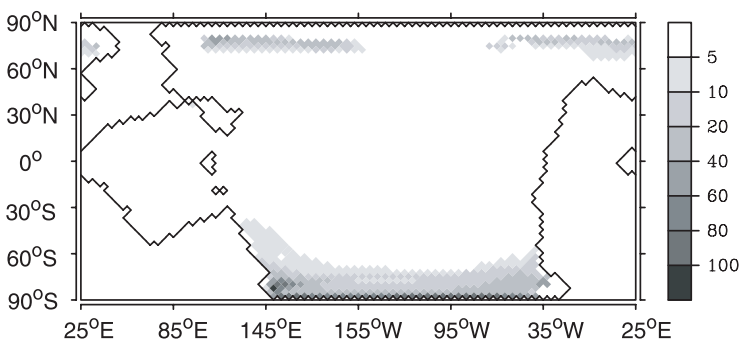

e) DEEP SEA HORIZONTAL VELOCITY [ $\left.\mathrm{cm} \mathrm{s}^{-1}\right]$ (WORDIAN 4XCO2)

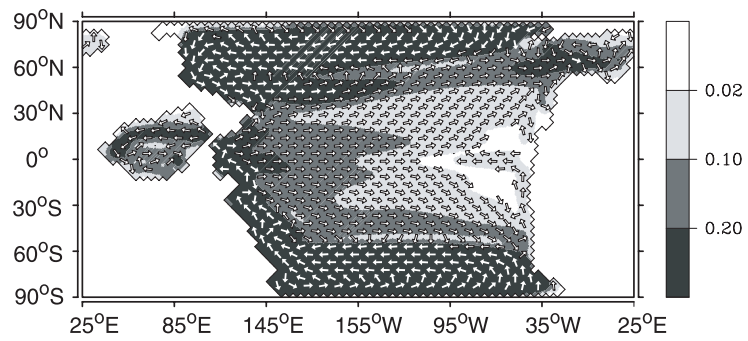

Figure 5. (a) Annual average of horizontal velocity at the ocean surface, (b) vertical velocity between surface layer and second model layer (contour interval: $1.5 \times 10^{-6} \mathrm{~m}$ $\mathrm{s}^{-1}$; stripple indicates downwelling), (c) barotropic stream function (contour interval: $10^{6} \mathrm{~m}^{3} \mathrm{~s}^{-1}$ ), (d) potential energy loss by convection, and (e) horizontal velocity in the deep sea $(\sim 3200 \mathrm{~m})$ for the Wordian climate with $4 \times \mathrm{CO}_{2}$. gravitational waves. In the western Tethys Sea, sea surface temperature shows maximum values of over $30^{\circ} \mathrm{C}$ and minimum values of $27^{\circ} \mathrm{C}$ in the lee of the equatorial island (South China) due to upwelling of subsurface water masses (Figure $5 \mathrm{~b}$ ). Strong temperature gradients (up to $20^{\circ} \mathrm{C}$ along the South Tethys Sea coast) are related to strong cooling during winter by outflow of cold air from the continent. Low salinities in the equatorial region are a consequence of well-developed ITCZ precipitation in the prescribed $\mathrm{Q}_{\mathrm{w}}$ forcing from the GENESIS 2 Wordian simulation. They are additionally influenced by tropical upwelling.

[21] The general features of the tropical ocean circulation in the eastern Panthalassa are comparable to the modern Pacific and show significant N-S differences, in contrast to an ocean simulation with idealized symmetrical land-sea distribution carried out by Kutzbach et al. [1990]. Typical current speeds are $5-10 \mathrm{~cm} \mathrm{~s}^{-1}$ in the equatorial region of the Panthalassa (Figure 5a). The simulated speeds of the western boundary currents are probably underestimated by a factor of 2 based on the comparison of the modern simulation with observations. This shortcoming of too sluggish simulated currents is typical for models with a coarse resolution and with no nonlinear advection of momentum.

[22] Strong subtropical and polar gyres in each hemisphere, centered around $30^{\circ}$ and $50^{\circ}$ latitude, are simulated for Panthalassa (Figure 5c). The strength of the subtropical gyre at $30^{\circ}$ latitude is about $60 \mathrm{~Sv}\left(1 \mathrm{~Sv}=10^{6} \mathrm{~m}^{3} \mathrm{~s}^{-1}\right)$ which is twice as strong as the gyre simulated for the modern subtropical South Pacific. The poleward directed currents in both hemispheres contribute to a warm temperate climate along the west coast of Gondwana (Figure 5a). On the east coast of Angara (Laurasia), a surface current streams southward similar to the modern Labrador Current and contribute to a cool climate condition around Mongolia (Figures $2 \mathrm{~b}-2 \mathrm{~d}$ ), which is in agreement with Wordian dataderived biomes [Rees et al., 1999, 2002]. However, the authors suggested, on the basis of floral similarities, that the cool climate could also be explained if the position of Mongolia would be moved toward Angara.

[23] The simulated deep ocean also differs from modern. Below $1500 \mathrm{~m}$ depth mean salinity is 34.25 and temperature is $5.4^{\circ} \mathrm{C}$ (compared to 34.66 and $3.8^{\circ} \mathrm{C}$ for the modern ocean simulation). Main locations for deep water formation (as inferred from maps of potential energy loss by convection; Figure 5d) are northeastern Panthalassa in the northern winter and southeastern Panthalassa in the southern winter. The deep circulation in high latitudes is opposite to the surface circulation (Figure 5e). A powerful westward flow moves across Panthalassa near $70^{\circ} \mathrm{S}$ latitude. At the east coast of Pangaea, deep western boundary currents circulate in both hemispheres toward the equator. This feature is in agreement with the idealized model of Stommel and Arons [1960]. They envisioned the ocean as a two-layer model with localized sinking in both hemispheres from the upper to the lower layer, and a wide spread slow return of water masses from the abyssal layer into the wind driven upper layer. In accordance with their theory, low current velocities with minima around $30^{\circ}$ latitude are simulated in the interior of Panthalassa, which might have implications for an accumulation of organic material from the surface. 


\section{WORDIAN (1XCO2)}

a) SEA SURFACE TEMPERATURE $\left[{ }^{\circ} \mathrm{C}\right]$

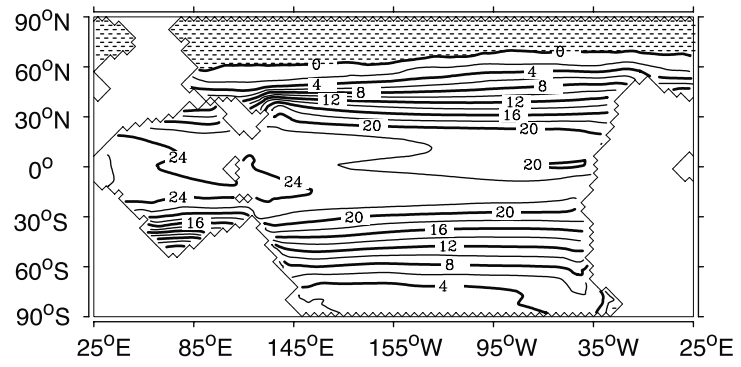

b) SURFACE AIR TEMPERATURE $\left[{ }^{\circ} \mathrm{C}\right]$

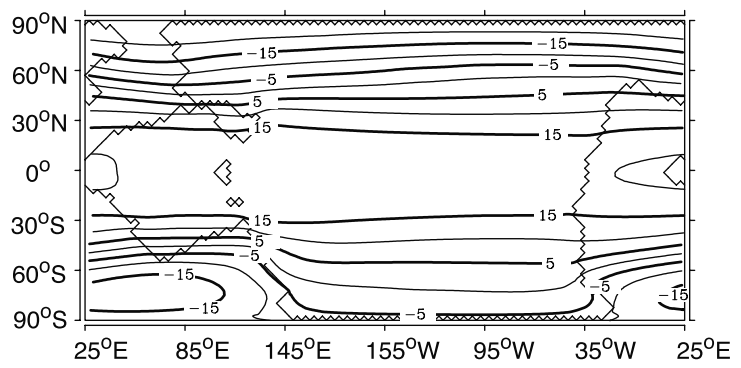

WORDIAN (8XCO2)

c) SEA SURFACE TEMPERATURE $\left[{ }^{\circ} \mathrm{C}\right]$

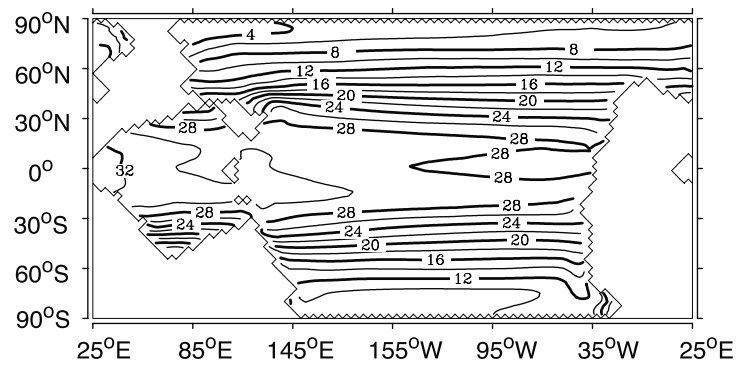

d) SURFACE AIR TEMPERATURE [ $\left.{ }^{\circ} \mathrm{C}\right]$

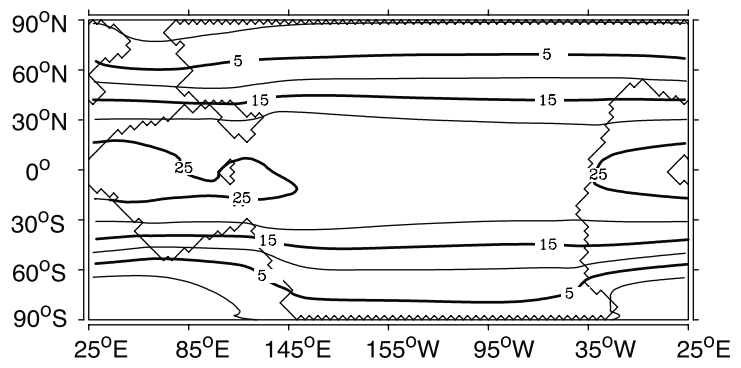

Figure 6. (left) Annual average of modeled sea surface temperature for the Wordian climate with $1 \times \mathrm{CO}_{2}$ (Figure 6a) and $8 \times \mathrm{CO}_{2}$ (Figure 6c) (contour interval: $2^{\circ} \mathrm{C}$ ). (right) Annual average of air surface temperature in ${ }^{\circ} \mathrm{C}$ for the $1 \times \mathrm{CO}_{2}$ (Figure $6 \mathrm{~b}$ ) and $8 \times \mathrm{CO}_{2}$ (Figure $6 \mathrm{~d}$ ) experiments (contour interval: $5^{\circ} \mathrm{C}$ ).

Remineralization and oxidation of the accumulated organic matter might cause anoxic conditions in these locations.

\subsection{Response of the Simulated Wordian Climate to Changes in Atmospheric $\mathrm{CO}_{2}$}

[24] To investigate the sensitivity of the ocean heat transport and ocean circulation to atmospheric $\mathrm{CO}_{2}$ levels, three additional experiments were carried out with $1 \times, 2 \times$, and $8 \times \mathrm{CO}_{2}$ levels and corresponding changes in the radiative forcing of $0,4.4$, and $13.1 \mathrm{~W} \mathrm{~m}^{-2}$ (in contrast to $8.7 \mathrm{~W} \mathrm{~m}^{-2}$ with $4 \times \mathrm{CO}_{2}$, our baseline). For these experiments, the EBM/LSG uses specified wind stress forcing and precipitation minus evaporation (P-E) forcing from two simulations, WORD- $1 \times \mathrm{CO}_{2}$ and WORD- $2 \times \mathrm{CO}_{2}$, which are analogous to the WORD-4 $\times \mathrm{CO}_{2}$ and WORD-8 experiment from Gibbs et al. [2002]. Differences in global average of sea surfaces temperatures between the $8 \times$ $\mathrm{CO}_{2}$ level and $1 \times \mathrm{CO}_{2}$ are $7.1^{\circ} \mathrm{C}$ (Table 1) and more than $8^{\circ} \mathrm{C}$ in the Tethys Sea (Figures $6 \mathrm{a}$ and $6 \mathrm{c}$ ). The $1 \times \mathrm{CO}_{2}$ simulation fails to generate moderate climate in southern Gondwana as a result of the cool surface temperatures, and hence is at odds with reconstructed biomes [Rees et al., 2002], while the $8 \times \mathrm{CO}_{2}$ simulation produces the most moderate climate (Figure 6c). However, the $8 \times \mathrm{CO}_{2}$ simulation produces a very warm midlatitude climate $\left(20^{\circ} \mathrm{C}\right.$ isoline at a latitude of $\sim 40^{\circ}$ ) and high-latitude climate, which are in conflict with BIOME reconstruction from Rees et al. [2002]. Pole to equator gradients of air surface temperature in the $1 \times \mathrm{CO}_{2}$ experiment (Figure 6b) are estimated to be $\sim 10^{\circ} \mathrm{C}$ higher than the $4 \times \mathrm{CO}_{2}$ baseline experiment because of effective sea ice albedo feedback in the Northern Hemisphere. The model simulations indicate a sensitive response of sea ice extent in the Northern Hemisphere to an increase of radiative greenhouse gas forcing (Figures $7 \mathrm{a}$ and $7 \mathrm{~b}$ ). Sea ice coverage in the Northern Hemisphere in the $1 \times \mathrm{CO}_{2}$ experiment would be at odds with estimates of water mass properties derived from the climate-sensitive sediments (see section 4). The area covered by sea ice is decreased by $\sim 1 / 3$ if the atmospheric $\mathrm{CO}_{2}$ concentration is doubled from the $1 \times \mathrm{CO}_{2}$ to $2 \times \mathrm{CO}_{2}$ (Figure $7 \mathrm{~b}$ and Table 1).

[25] Using the zonal average profile of net radiation for annual mean conditions at the top of the atmosphere $\left(\mathrm{Q}_{\mathrm{TA}}\right)$, we can estimate the total poleward heat transport in the ocean-atmosphere system $\left(\mathrm{T}_{\mathrm{TOT}}\right)$ as a sum of the poleward heat transport by the atmosphere $\left(\mathrm{T}_{\mathrm{A}}\right)$ and by the ocean $\left(\mathrm{T}_{\mathrm{OC}}\right)$ :

$$
\begin{gathered}
\mathrm{Q}_{\mathrm{TA}}=\int_{\text {top }}(1-\mathrm{A}) \mathrm{Q}_{\mathrm{SW}}-\mathrm{Q}_{\mathrm{LW}} \mathrm{dt} \approx 0 \\
\mathrm{~T}_{\mathrm{A}}+\mathrm{T}_{\mathrm{OC}}=-\int_{\phi^{\prime}=\phi}^{\pi / 2} \mathrm{Q}_{\mathrm{TA}} 2 \pi \mathrm{R}^{2} \cos \phi^{\prime} \mathrm{d} \phi^{\prime}
\end{gathered}
$$

where $\mathrm{Q}_{\mathrm{SW}}$ and $\mathrm{Q}_{\mathrm{LW}}$ are short-wave and long-wave radiation, $\mathrm{A}$ is albedo and $\mathrm{R}$ is Earth radius. Values of 


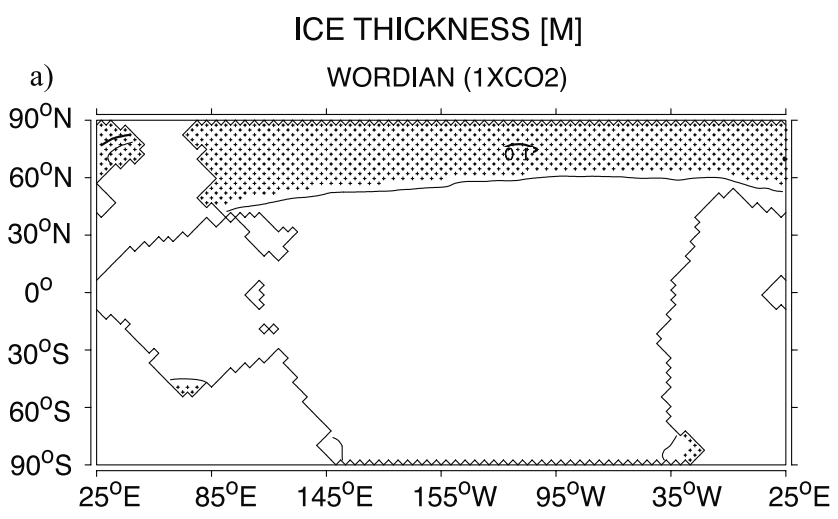

b) WORDIAN (2XCO2)

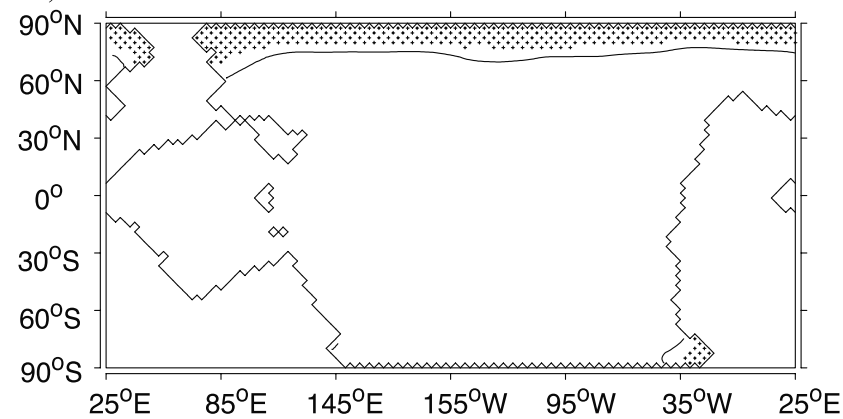

Figure 7. Annual average of sea ice distribution (m) for (a) the $1 \times \mathrm{CO}_{2}$ and (b) $2 \times \mathrm{CO}_{2}$ experiments (contour interval: $0.1 \mathrm{~m}$ ).

$\mathrm{Q}_{\mathrm{TA}}$ for the different experiments (Table 1) are very small and within in the range of the observational uncertainty of about $0.8 \mathrm{~W} \mathrm{~m}^{-2}$ [Oort and Peixoto, 1983]. The global annual mean and zonally averaged heat transport for the $4 \times$ $\mathrm{CO}_{2}$ experiment is displayed in Figure 8a. The global heat transport has some similarities to the modern one (not shown here) and is in agreement with other Phanerozoic climate studies [Poussart et al., 1999]. The transport is generally dominated by the atmosphere, but in southern low latitudes by the ocean. The oceanic heat transport for the present day (Figure 8b) is comparable with previous simulations of Maier-Reimer et al. [1993], which is at the lower bounds of observations as a result of the coarse model resolution. Our simulations for the Wordian produce considerably larger heat transport for the middle and high latitudes (up to $1 \mathrm{PW}$ at $50^{\circ} \mathrm{S}$; Figure $8 \mathrm{~b}$ ) than found in the study of Gibbs et al. [2002] where the ocean heat transport estimate is based on a heat diffusion parameterization. However, these results are not directly comparable due to the difference of the models. Our results are more in agreement with earlier results of Kutzbach and Ziegler [1993] derived from a Permian-like ocean simulation with idealized symmetric land-sea distribution [Kutzbach et al., 1990]. The oceanic heat transport changes significantly as the $\mathrm{CO}_{2}$ level changes, especially in the Northern Hemisphere. In general, the strong convergence of the heat transport (compare midlatitude transport to polar transport; Figure 8) implies that the high-latitude ocean is providing considerable heat to the atmosphere (see Figures 2 and 5).
[26] There are also large changes in the meridional overturning circulation. For $1 \times \mathrm{CO}_{2}$, large sea ice coverage in the Northern Hemisphere prevents deep-water formation and a strong heat exchange with the atmosphere (Figure $9 a)$ in the northern high latitudes resulting in a thermohaline circulation dominated by a southern circulation cell (Figure 10a). Experiments with increased $\mathrm{CO}_{2}$ levels have decreased northern sea ice coverage, increased formation of deep water in the northern high latitudes, increased seato-air heat exchange in polar regions (Figures $2 \mathrm{~d}, 9 \mathrm{~b}$, and 9c), and strengthened northern meridional circulation cell (Figures 10c and 10d). However, even with highest $\mathrm{CO}_{2}$ levels the southern circulation cell is stronger, which must be a consequence of the asymmetrical land-sea distribution (a symmetrical cell can be obtained if symmetrical continent configuration and surface buoyancy forcing is applied [Kutzbach et al., 1990]). A detailed study of this asymmetry is still underway.

\subsection{Response to Circumpolar Currents Associated With Polar Seaways}

[27] Ziegler [1998] suggested that the absence of warm polar currents might explain the high-latitude cold bias of recent Permian climate studies as inferred from data/model comparisons [Rees et al., 2002]. To explore this possibility in greater detail, experiments $4 \times \mathrm{CO}_{2} \mathrm{~N}$ and $4 \times \mathrm{CO}_{2} \mathrm{~S}$ use the same boundary conditions as the Wordian baseline experiment but include the possibility of a northern and a southern circumpolar current by removing land between $70^{\circ}$ to $90^{\circ}$ in northern $(\mathrm{N})$ and southern $(\mathrm{S})$ latitude. The resulting changes in the high-latitude ocean temperature have an impact on the climate conditions over highlatitude landmasses (Figure 11). With a circumpolar current, polar air surface temperatures increased by $2^{\circ}-8^{\circ} \mathrm{C}$ (Figures 11a and 11b) and are above the freezing point in the annual averages (not shown). Because the boundary conditions used in our baseline experiment (section 2.2) exaggerated the amount of polar land somewhat, these sensitivity experiments provide a partial explanation for the cold bias of previous high-latitude simulations. A strong sea to air heat flux of more than $60 \mathrm{~W} \mathrm{~m}^{-2}$ (Figures 11c and 11d) is simulated in the polar seaways (Figures 11e and 11f). The positive heat fluxes into the polar atmosphere contribute to positive air temperature differences of up to $8^{\circ} \mathrm{C}$ warmer than the simulated air surface temperatures in the Wordian baseline simulation (section 3.1). The increased air temperatures result in a more mild polar climate of the adjacent coasts over both Gondwana and Angara, which is comparable with the moderate marine climate on the modern Norwegian Coast (e.g., near Bodö) strongly influenced by the warm North Atlantic Current. In experiment $4 \times \mathrm{CO}_{2} \mathrm{~N}$, the warm eastward moving currents of middle north latitudes bend to the north (comparable with the flow of the present North Atlantic current into the Arctic Region) and joins the northern circumpolar current (Figure 11e). A similar feature is simulated with a southern circumpolar current (Figure 11f). The existence of the southern polar seaway causes a reduction of the southern meridional overturning circulation by about $10 \mathrm{~Sv}$ (not shown) which could be 
a)

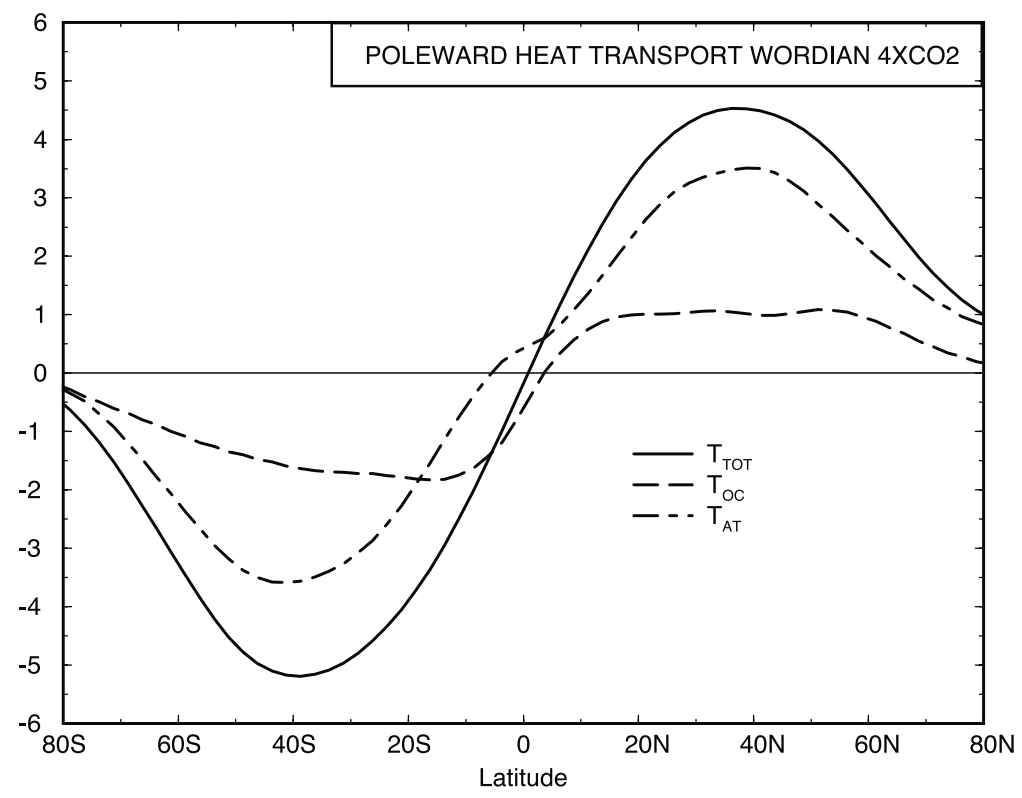

b)

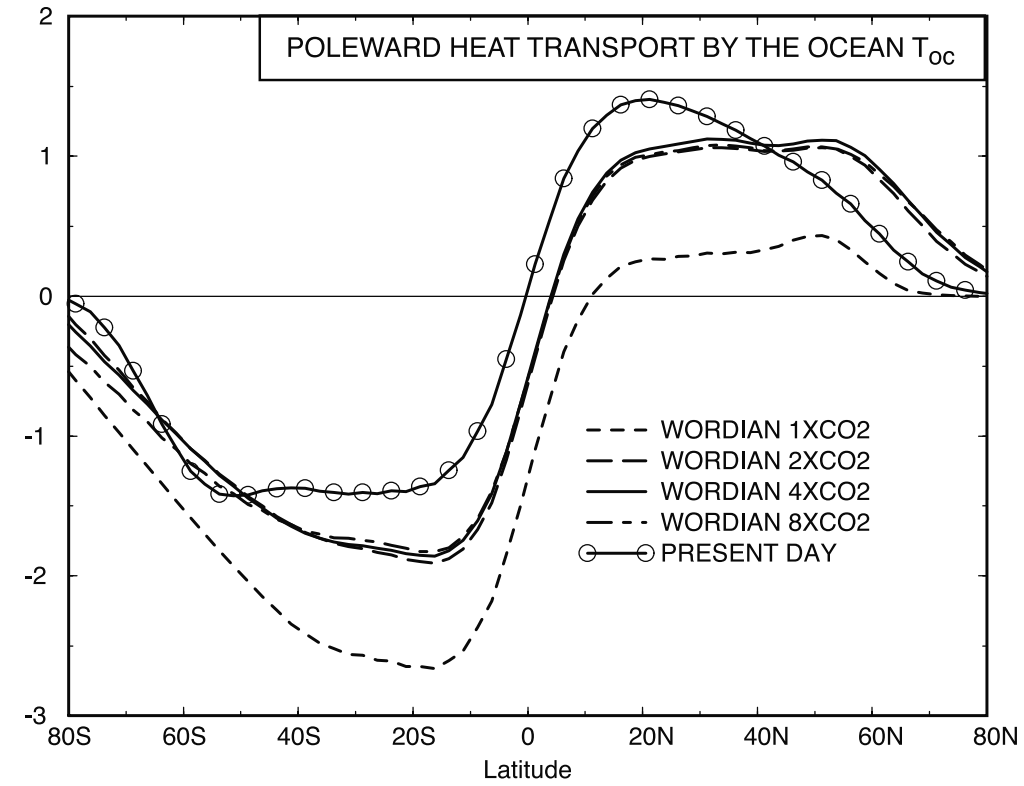

Figure 8. Meridional profile of the poleward transport of heat in PW $\left(10^{15} \mathrm{~W}\right)$. (a) Heat transport by the ocean $\left(\mathrm{T}_{\mathrm{OC}}\right)$, atmosphere $\left(\mathrm{T}_{\mathrm{A}}\right)$, and total heat transport $\left(\mathrm{T}_{\mathrm{TOT}}=\mathrm{T}_{\mathrm{A}}+\mathrm{T}_{\mathrm{OC}}\right)$ for the Wordian climate with $4 \times$ $\mathrm{CO}_{2}$. (b) Heat transport by the ocean $\left(\mathrm{T}_{\mathrm{OC}}\right)$ for the $1 \times \mathrm{CO}_{2}, 2 \times \mathrm{CO}_{2}, 4 \times \mathrm{CO}_{2}, 8 \times \mathrm{CO}_{2}$, and present-day experiments.

related to a northward Ekman transport by westerlies [Gibbs et al., 2002, Figure 9] at the southern tip of Gondwana.

\subsection{Response to Changes of the Orbital Parameters}

[28] Two extreme orbital configurations, one with hot summer orbit (HSO) and one with cold summer orbit (CSO) are considered (section 2.3). The orbital configurations are selected such that the Southern Hemisphere summer will be warmest with HSO and Northern Hemisphere will be warmest with $\mathrm{CSO}$. The two experiments used the $4 \times \mathrm{CO}_{2}$ baseline and are referred to as $4 \times \mathrm{CO}_{2} \mathrm{HSO}$ and $4 \times \mathrm{CO}_{2}$ CSO. The specified wind stress and P-E for these experiments are taken from WORD- $8 \times \mathrm{CO}_{2}, \mathrm{HSO}$ and WORD- $4 \times$ $\mathrm{CO}_{2}$, CSO described by Gibbs et al. [2002]. High-latitude summer temperatures are sensitive to changes in the orbital configuration and play a critical role in snow accumulation and formation of continental ice sheets in these areas. Early 

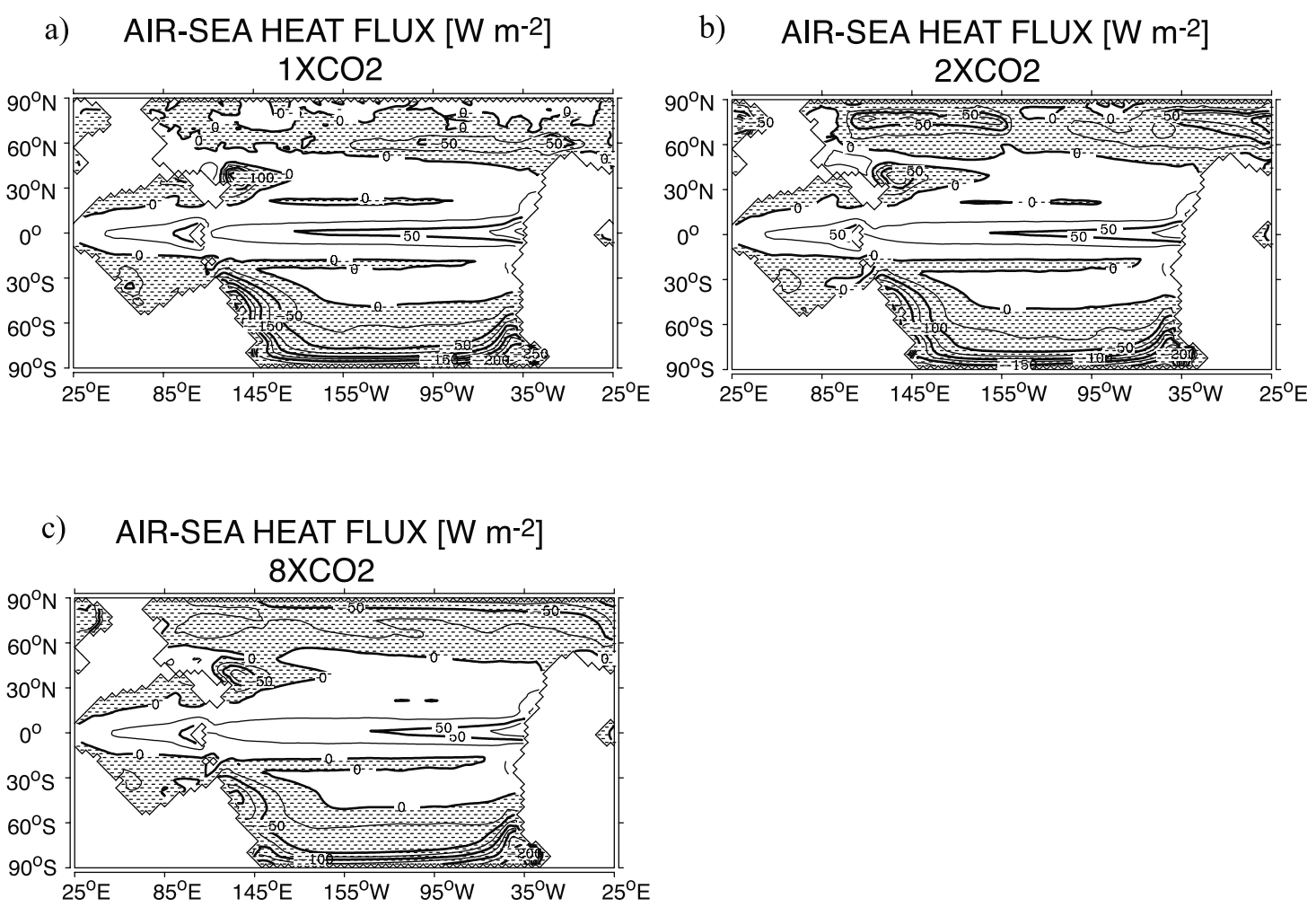

Figure 9. Annual average of modeled air-to-sea heat flux in $\mathrm{W} \mathrm{m}^{-2}$ for the Wordian climate with (a) $1 \times$ $\mathrm{CO}_{2}$, (b) $2 \times \mathrm{CO}_{2}$, and (c) $8 \times \mathrm{CO}_{2}$ (stripple indicates flux to the atmosphere; contour interval: $25 \mathrm{~W} \mathrm{~m}^{-2}$ ).

Jurassic EBM simulations result in maximum surface temperature changes of up to $\sim 15^{\circ} \mathrm{C}$ [Crowley et al., 1992]. Simulations of Gibbs et al. [2002] indicate that significant differences between HSO and CSO configurations result in some changes in south polar snow accumulation and hence affect high-latitude climate reconstructions.

[29] Our simulations show HSO minus CSO differences in summer surface temperatures for the Southern Hemisphere (Figure 12a) of $\sim+20^{\circ} \mathrm{C}$ centered over Gondwana and for the Northern Hemisphere of $\sim-10^{\circ} \mathrm{C}$ centered over Euramerica (Figure 12b). These significant temperature changes have implications for the length of the growing season and calculation of modeled biome in a fully coupled oceanatmosphere climate model. The positive temperature anomaly in the Northern Hemisphere in Figure 12a may be due to a positive ice albedo feedback mechanism in the WSO experiment. Changes of the orbital parameters have only little effect on the global annual mean air surface and ocean temperatures (Table 1), similar to results from the Late Ordovician climate sensitivity experiments of Poussart et al. [1999].

\section{Comparison With Climate-Sensitive Sediments}

[30] Ziegler et al. [1998] constructed climate maps for the Wordian (Figure 13a) based upon Wordian sediments and their present-day relationship of sediments to characteristic water masses (Table 2). The climate-sensitive sediments have been compared with modern marine climate properties, in particular temperature, salinity and productivity related effects. The water mass boundaries listed in Table 2 are based on a summary of parameters derived from world ocean atlases. The boundaries of characteristic water masses (defined by specific temperature and salinity ranges and strength in upwelling) are chosen somewhat arbitrarily because it is difficult to select particular values that universally represent significant climate changes and transitions on the Paleozoic timescale. The water masses of Ziegler et al. [1998] are classified in eight categories (Table 2). These are briefly described (Figure 13a) and then compared with our model simulations for the Wordian baseline experiment $(4 \times$ $\mathrm{CO}_{2}$ ) unless otherwise noted (Figure 13b).

\subsection{Glacial Climate}

\subsubsection{Data}

[31] Occurrence of permanent ice flows (like most of the modern Arctic Ocean, or ice shelf of Antarctica) generated by outflow of cold air. Tills could be expected along mountainous coasts of these regions. Sediments of this category are known in the Early Permian but have not been found in Wordian rocks.

\subsubsection{Model}

[32] In the ocean, sea ice cover (sea surface temperatures $<-1.8^{\circ} \mathrm{C}$ ) is not simulated in the $4 \times \mathrm{CO}_{2}$ Wordian baseline experiment, but occurs with lowered $\mathrm{CO}_{2}$.

\subsection{Cold Temperate Climate}

\subsubsection{Data}

[33] The water masses are defined by the extent of sea ice in the winter season and correspond closely to the $0^{\circ} \mathrm{C}$ isotherm (e.g., similar to conditions in the modern Labrador 


\section{MERIDIONAL CIRCULATION [SV]}

a)

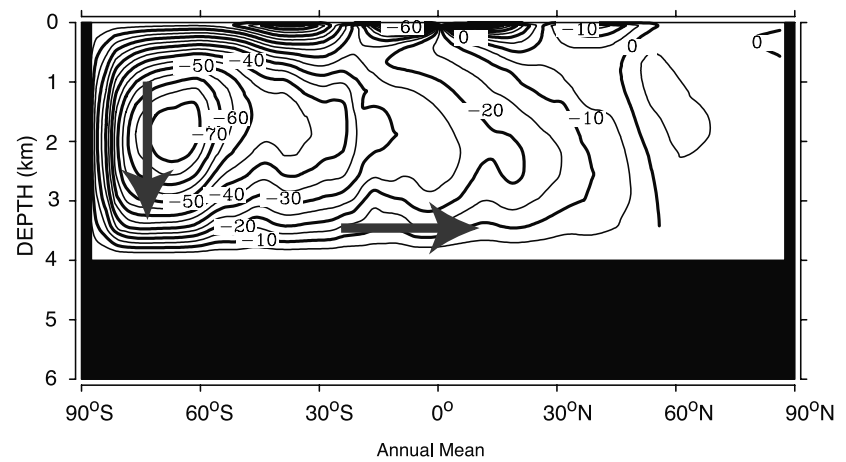

c)

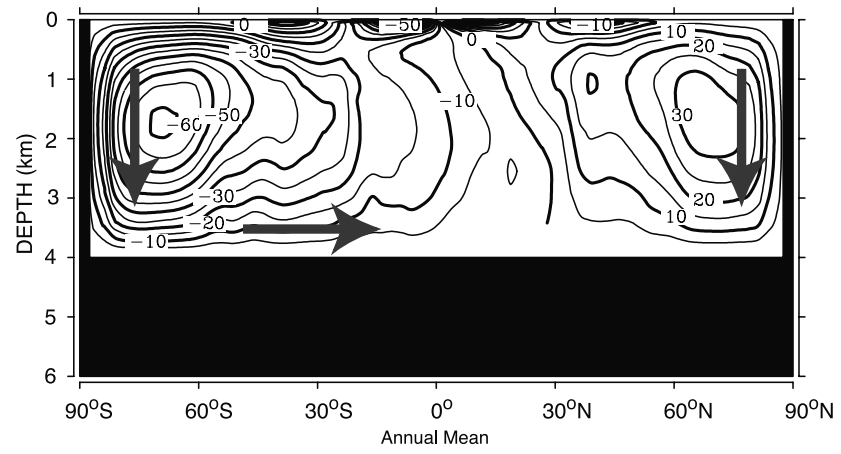

b)

WORDIAN (2XCO2)

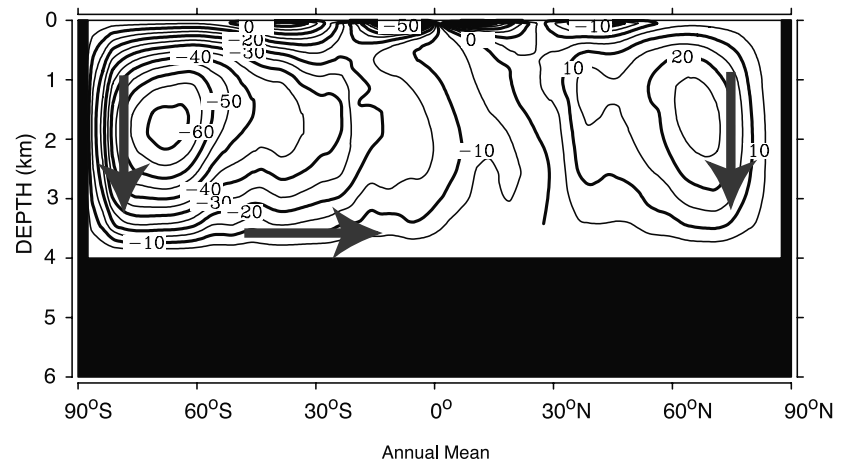

d)

\section{WORDIAN (8XCO2)}

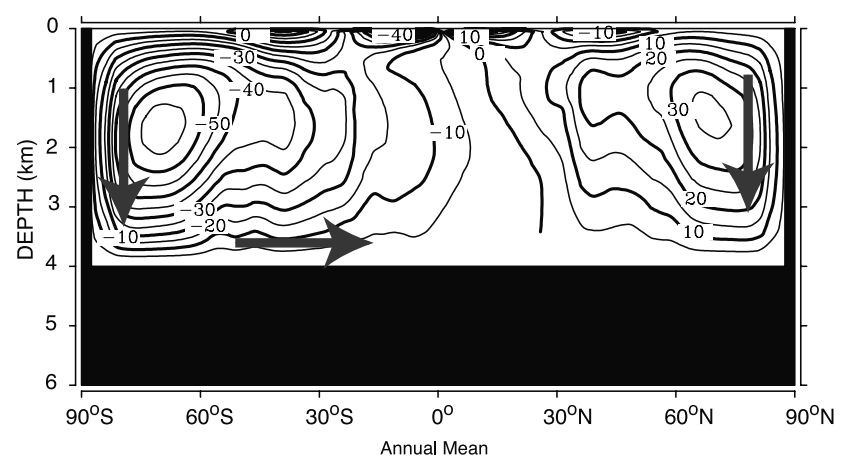

Figure 10. Zonally averaged meridional circulation for the Wordian climate with (a) $1 \times \mathrm{CO}_{2}$, (b) $2 \times$ $\mathrm{CO}_{2}$, (c) $4 \times \mathrm{CO}_{2}$, and (d) $8 \times \mathrm{CO}_{2}$ (contour interval: $5 \mathrm{~Sv}=5 \times 10^{6} \mathrm{~m}^{3} \mathrm{~s}^{-1}$ ).

Current). Dropstones and rhythmites would be indicative of this environment in the fossil record and have been identified in the geological record of Tasmania along the southeastern coast of Gondwana (Figure 11a).

\subsubsection{Model}

[34] The model (Figure 13b) simulates moderate conditions along the south-polar east coast from Gondwana where data indicate a cold temperate condition. Warm conditions (sea surface temperatures of $\sim 4^{\circ} \mathrm{C}$ in winter time; Figure 3c) are related to the polarward directed currents modeled for these regions. In the observations, the Tasmanian seas might represent a re-entrant in the coast, isolated from the warming effects of the open ocean currents.

\subsection{Wet Temperate Climate}

\subsubsection{Data}

[35] Temperatures between $0^{\circ} \mathrm{C}$ and $20^{\circ} \mathrm{C}$ and brackish conditions (salinity below 32) define this climate zone (for example modern Baltic Sea or Canadian West Coast). Peats are characteristically developed around the margins of these characteristic water masses and organic muds are commonly associated in the center of these areas with high precipita- tion. The swamp deposits depend on consistency of rainfall through the annual cycle, or at least through the warmer months [Lottes and Ziegler, 1994], and for confined seaways or broad shallow shelves this translates into lowered salinities. The associated surface runoff provides for abundant nutrients and a stratified water column which in turn allows for organic preservation. The geological data (Figure 13a) for this water mass are best seen around Angara but also occur around southern Gondwana.

\subsubsection{Model}

[36] Simulated high precipitation [Gibbs et al., 2002] and low salinities (Figure 4) of the high-latitude west coasts of Angara agree with the geological recognition of the wet temperate climate category. In addition, model results show wet temperate regions in northern India along the shore of the southern Tethys Sea similar to the geological findings. These climate conditions are related to the advection of moist tropical air masses and enhanced precipitation. Interestingly, the model shows a wider extent of this water mass type than had been inferred from the geological data but the model results are nevertheless entirely consistent with the data. Here the original water mass interpretation was simply too conservative. 
a) 4XCO2N-4XCO2 DIFFERENCE IN
AIR SURFACE TEMPERATURE $\left[{ }^{\circ} \mathrm{C}\right]$

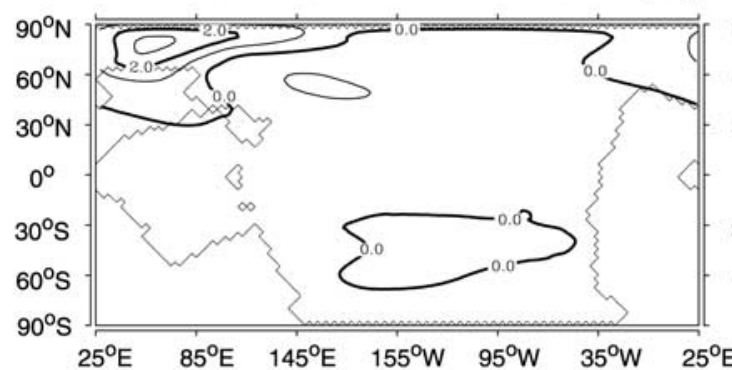

c)

AIR-SEA HEAT FLUX [W m-2] $4 \mathrm{XCO} 2 \mathrm{~N}$

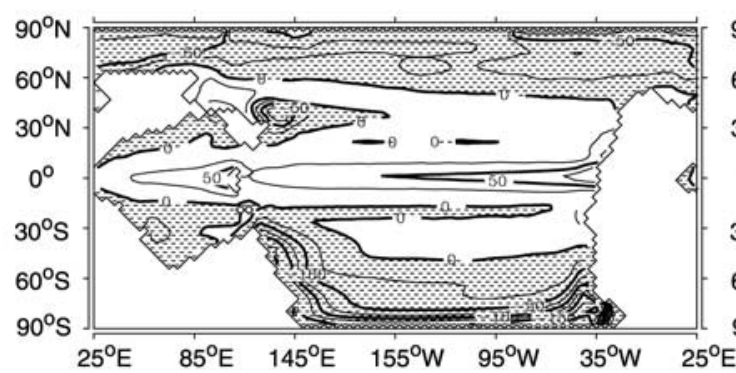

e) HORIZONTAL VELOCITY $[\mathrm{cm} / \mathrm{s}]$ $4 \times C O 2 N$

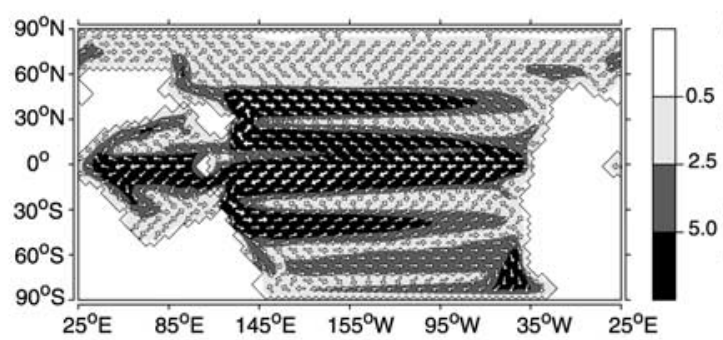

b) 4XCO2S-4XCO2 DIFFERENCE IN
AIR SURFACE TEMPERATURE [ $\left.{ }^{\circ} \mathrm{C}\right]$

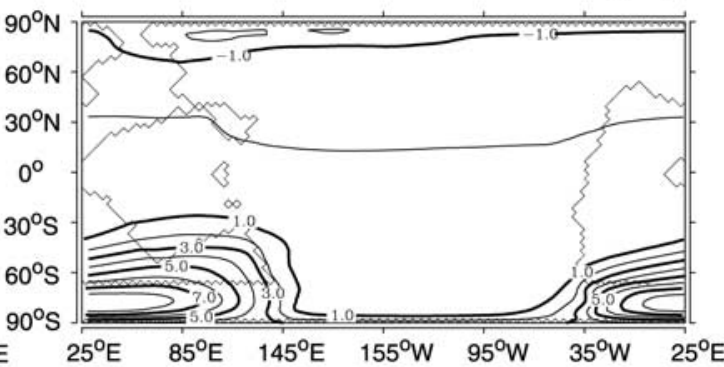

d)

\section{AIR-SEA HEAT FLUX [W $\left.\mathrm{m}^{-2}\right]$} $4 \mathrm{XCO} 2 \mathrm{~S}$

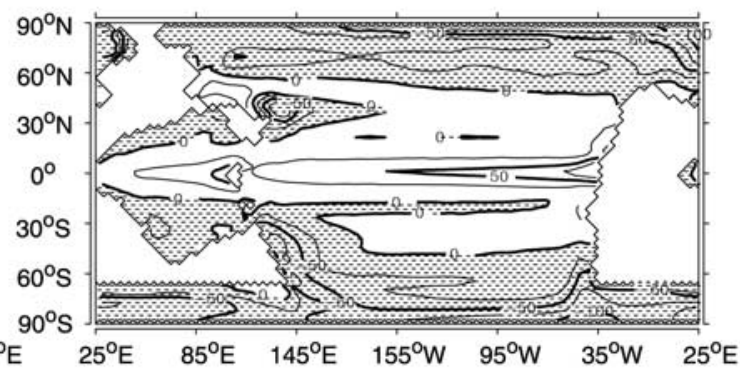

f) HORIZONTAL VELOCITY [cm/s] $4 \mathrm{XCO} 2 \mathrm{~S}$

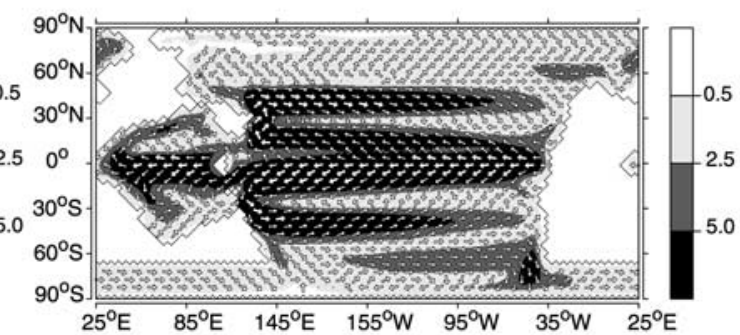

Figure 11. Annual average of modeled difference in air surface temperature in ${ }^{\circ} \mathrm{C}$ between the $4 \times \mathrm{CO}_{2}$ experiment with (a) northern circumpolar seaway $4 \times \mathrm{CO}_{2} \mathrm{~N}$ and (b) southern circumpolar seaway $4 \times$ $\mathrm{CO}_{2} \mathrm{~S}$ and the $4 \times \mathrm{CO} 2$ baseline experiment (contour interval: $5^{\circ} \mathrm{C}$ ). Annual average of modeled air-tosea heat flux in $\mathrm{W} \mathrm{m}^{-2}$ (c) for $4 \times \mathrm{CO}_{2} \mathrm{~N}$ and (d) for $4 \times \mathrm{CO}_{2} \mathrm{~S}$ (stripple indicates flux to the atmosphere; contour interval: $25 \mathrm{~W} \mathrm{~m}^{-2}$ ). Annual average surface current velocities for (e) $4 \times \mathrm{CO}_{2} \mathrm{~N}$ and (f) for $4 \times$ $\mathrm{CO}_{2} \mathrm{~S}$.

\subsection{Temperate Climate}

\subsubsection{Data}

[37] Temperature in this climate zone ranges $0^{\circ} \mathrm{C}$ and $20^{\circ} \mathrm{C}$ and salinity between 32 and 37 (e.g., Kuroshio Current for modern climate). No particular climate indicators have been identified for this zone, but peats are quite common due to low evaporation rates in mid to high latitudes.

\subsubsection{Model}

[38] The equatorial margin of the water mass in this climate zone is placed around $30^{\circ}$ latitude for the Wordian $4 \times \mathrm{CO}_{2}$ simulation (Figure 13b), similar to the reconstructed equatorial margin from climate-sensitive sediments
(Figure 13a). The bias between model results and the reconstructions on the West Coast of Pangaea can be explained by the more poleward location of main upwelling areas, which are centered in the model around the equator as a response to the wind stress and bathymetry.

\subsection{Cool Subtropical Upwelling Zones}

\subsubsection{Data}

[39] This category is defined by zones, which are mainly limited to the subtropical belt and equatorial region where Ekman-induced upwelling produces high organic productivity and nutrient content. Formation of organic muds and phosphorites constitutes the recognition of these upwelling 


\section{Surface Air Temperature $\left[{ }^{\circ} \mathrm{C}\right]$}

Hot Summer Orbit - Cold Summer Orbit

a)

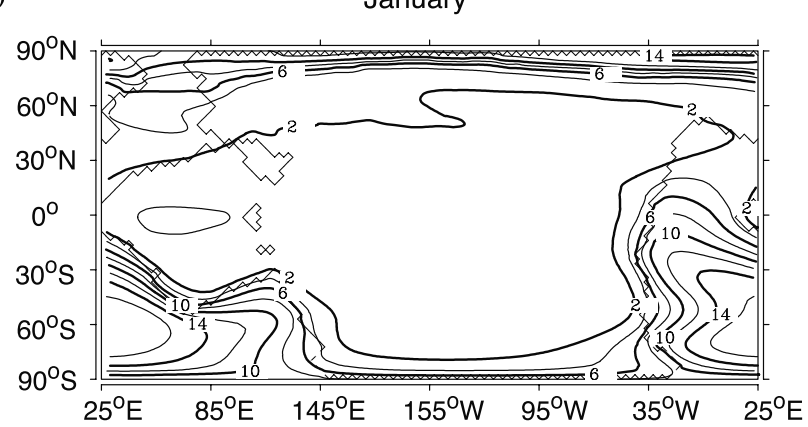

b)

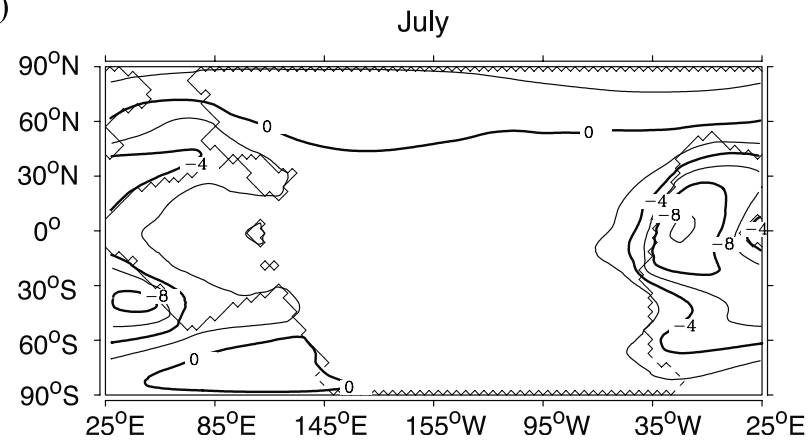

Figure 12. Difference of air surface temperature in (a) January and (b) July between the simulation with hot summer orbit $\left(4 \times \mathrm{CO}_{2} \mathrm{HSO}\right)$ and cold summer orbit $(4 \times$ $\mathrm{CO}_{2} \mathrm{CSO}$ ) configuration. Note that the cold summer orbit configuration for the Southern Hemisphere corresponds to a hot summer orbit configuration for the Northern Hemisphere (contour interval: $2^{\circ} \mathrm{C}$ ).

zones. No attempt was made to map the equatorial upwelling zone as the Permian ocean floor has been subducted and the sedimentary evidence destroyed.

\subsubsection{Model}

[40] Upwelling is mapped as green shaded areas and is defined to have upward current velocities greater than $1 \times$ $10^{-6} \mathrm{~m} \mathrm{~s}^{-1}$ (Figure 13b). Typical regions are the coastal upwelling along the west coast of Gondwana at locations comparable with modern Californian coast or the Coast of Peru. A strong upwelling belt is located along the Equator similar to the modern Pacific and around islands. This equatorial upwelling includes shallow platform seas of the South China microcontinent and is actually supported by the presence of organic rich shales and phosphorites. These were originally interpreted as indicating the wet tropical water mass (Figure 13a) but the upwelling intrepretation fits equally well.

\subsection{Dry Subtropical Climate}

\subsubsection{Data}

[41] Areas with low precipitation minus evaporation with salinity greater than 37 provide favorable conditions for evaporite deposition in coastal lagoons and broad platform seaways (Figure 13a).

\subsubsection{Model}

[42] Low precipitation and high salinities are simulated along the southeastern Tethys Sea (Figure 4), South China, or the West Coast of Euramerica in agreement with the geological evidence. In addition, embayments along the northern coast of Euramerica have been identified to be dry from model simulations [Gibbs et al., 2002] and geological data. However, the ocean model does not resolve this area because of the coarse resolution of the model (Figure 13b).

\subsection{Tropical Climate}

\subsubsection{Data}

[43] Surface temperatures greater than $20^{\circ} \mathrm{C}$ and normal salinity, which allows carbonate buildup and bottom productivity, characterize this water mass (Figure 13a). Carbonate buildups are generally not found in the geological past above $35^{\circ}$ of latitude, as shown by paleomagnetic data [Hulver et al., 1997]. This latitudinal restriction constitutes the zone of light penetration to the seafloor as controlled by the Sun's zenith angle [Ziegler et al., 1984].

\subsubsection{Model}

[44] Model simulations (Figure 13b) are in agreement with climatic reconstructions (Figure 13a), but differences on the west coast of Pangaea are associated with upwelling areas, which cannot be entirely resolved with the coarse model resolution.

\subsection{Wet Tropical \\ 4.8.1. Data}

[45] Wet tropical areas are defined to have sea surface temperatures above $20^{\circ} \mathrm{C}$ and relatively brackish conditions (salinities below 32). Organic-rich shales do not seem to be associated with wet tropical climate at modern times, but they almost certainly occurred in the Wordian (e.g., in the South China Sea, Figure 13a).

\subsubsection{Model}

[46] Wet tropical conditions are simulated in the southern Tethys Sea, for the east coast of North China, and the southern coast of South China (Figure 13b). Such areas are characterized by high river runoff, and/or high precipitation (e.g., along the intertropical convergence zone) and correlate well with tropical coals of these areas.

\section{Summary and Conclusions}

[47] We simulated the Wordian climate with a coupled atmosphere-ocean model of intermediate complexity (EBM and LSG) using realistic land-ocean geometry. The model results $\left(4 \times \mathrm{CO}_{2}\right.$ baseline experiment) produce (1) surface water masses with temperature characteristics which are warmer and fresher than at modern times in the high latitudes, (2) a strong westward equatorial current which is blocked by islands at the eastern Tethys Sea, (3) warm poleward directed currents along the Tethys coast and east coast of Gondwana, (4) cold equatorward currents along the east coast of Angara, (5) large meridional overturning circulation cells with deep water formation at both poles, and (6) a warm deep ocean with low current speed in the 
a)

WORDIAN (267-264 MA)

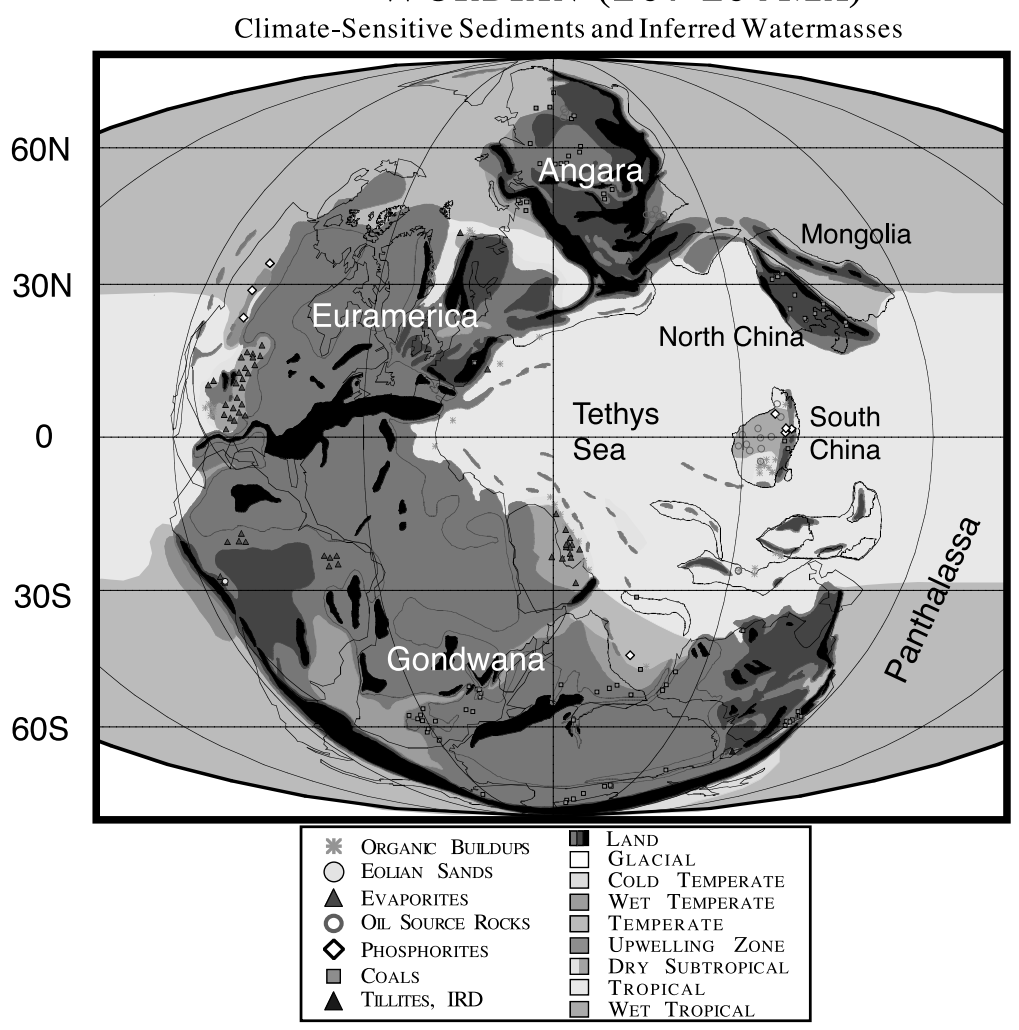

b)

\section{MODEL SIMULATION (4xCO2)}

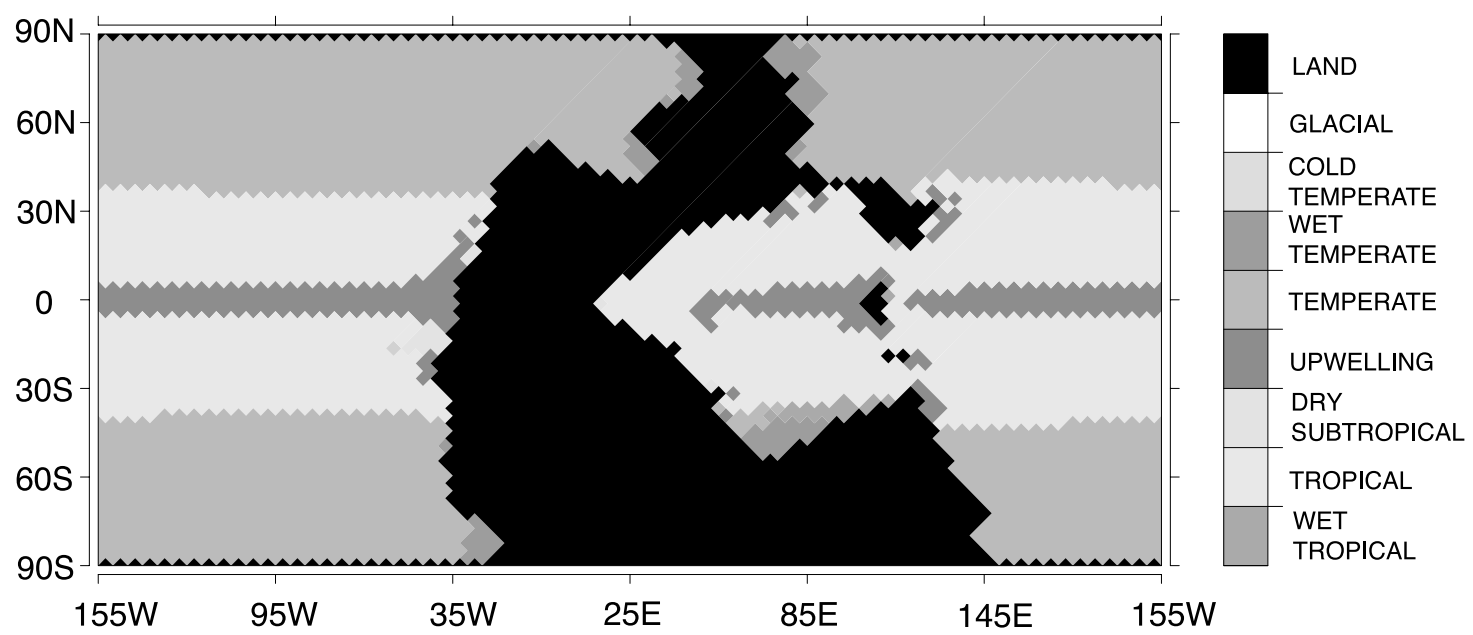

Figure 13. (a) Wordian (Kazanian, early Maokouan) climate sensitive sediments and reconstructed water masses from Ziegler et al. [1998]. (b) Water mass classification derived from the climate simulation with $4 \times \mathrm{CO}_{2}$ using the classification scheme of Table 2. See color version of this figure at back of this issue.

eastern equatorial Panthalassa. The model results were compared with climate-sensitive sediments (section 4) and with other climate simulations. The $4 \times \mathrm{CO}_{2}$ baseline experiment shows the best agreement with the paleoclimatic data (section 4). Our experiments suggest that very low $\mathrm{CO}_{2}$ and very high concentrations would cause significant datamodel disagreements. Low $\mathrm{CO}_{2}$ concentrations $\left(1 \times \mathrm{CO}_{2}\right)$ would more likely be associated with a glacial climate 
Table 2. Surface Water Mass Classification ${ }^{a}$

\begin{tabular}{lll}
\hline Climate Zone & \multicolumn{1}{c}{ Water Mass Essentials } & Geological Recognition \\
\hline Glacial & surface permanently frozen; SST $<-1.8^{\circ} \mathrm{C}$ & marine till \\
Cold temperate & winter ice flows; SST $-1.8-0^{\circ} \mathrm{C}$ & dropstones, rhythmites \\
Wet temperate & brackish surface water; SST $0-20^{\circ} \mathrm{C}$, salinity $<32$ & temperate peats, organic rich shales \\
Temperate & mixed water column; SST $0-20^{\circ} \mathrm{C}$, salinity $32-37$ & clastics \\
Cool subtropical & upwelling currents; vertical velocity w $>1 \times 10^{-6} \mathrm{~m} \mathrm{~s}^{-1}$ & organic-rich shales, phosphorites, cherts \\
Dry subtropical & high evaporation; salinity $>37$ & gypsum, halite, sabkha facies \\
Tropical & deep light penetration; SST $>20^{\circ} \mathrm{C}$, salinity $32-37$ & carbonates, oolites, coralgal reefs \\
Wet tropical & high precipitation or continental runoff; SST $>20^{\circ} \mathrm{C}$, salinity $<32$ & tropical peats, muddy sediments \\
\hline
\end{tabular}

${ }^{\mathrm{a}}$ Following Ziegler et al. [1998].

whereas high $\mathrm{CO}_{2}\left(8 \times \mathrm{CO}_{2}\right.$ experiment $)$ concentrations simulate too warm conditions in the high latitudes. We showed that existence of circumpolar currents in polar seaways would influence the temperature of adjacent high-latitude coasts. In comparison with the previous study of Gibbs et al. [2002], temperature changes over Gondwana were simulated to be up to $15^{\circ} \mathrm{C}$ higher in the annual mean. We also infer from our simulations that changes of the astronomical parameters have a significant impact on the climate over Gondwana, in general agreement with previous studies [Crowley et al., 1992]. The baseline simulation $(4 \times$ $\mathrm{CO}_{2}$ ) has a significantly warmer polar climate then the modern, owing to increased flux of heat from ocean to atmosphere in high latitudes. The results suggest that a moderate climate over South Gondwana could be reproduced by the following two conditions: (1) an atmospheric $\mathrm{CO}_{2}$ concentration of at least 4 times present levels and/or (2) the existence of a south polar seaway that further increases the heat flux to the atmosphere from the ocean. With these prescriptions, the simulated moderate climate over South Gondwana agrees reasonably well with geological data from climate-sensitive sediments and phytogeographic patterns. The simulated Panthalassa deep-sea circulation shows a high sensitivity to the ice-albedo feedback and radiative greenhouse gas forcing with strong N-S asymmetry at low $\mathrm{CO}_{2}$ levels and moderate asymmetry at high $\mathrm{CO}_{2}$ levels. Regions of slow currents in the deep Panthalassa have implications for carbon accumulation and low oxygen conditions.

[48] Although these results lend additional insight into possible climate processes of the Wordian, there are several simplifications that must be noted. The sensitivity of the simulated deep sea circulation to $\mathrm{CO}_{2}$ radiative forcing may well be different for different coupled ocean-atmosphere models as documented for modern and future $\mathrm{CO}_{2}$ scenarios in the recent IPCC2001 report [Cubasch et al., 2001]. For example, the magnitudes and locations of deep water formation are significantly different in different models. Moreover, important processes (such as an interactive hydrological cycle and interactive atmosphere-ocean dynamics) are not included in our model. However, analyses with a coupled atmosphere-ocean study of the role of air-sea flux components in $\mathrm{CO}_{2}$-induced climate changes [Mikolajewicz and Voss, 2000] have shown one can investigate the effect of individual components of air-sea interactions using partially coupled simulations.

[49] The ocean model used for this study has reproduced many of the qualitative features of the global ocean circu- lation and marine tracer distributions for modern and past times. However, a limitation arises from the use of a noneddy coarse resolution model which underestimates the strength of the western boundary currents. A more refined model with eddy-resolving grid size will probably yield a more realistic simulation of the western boundary currents and locations of deep water formation.

[50] There were additional limitations to this study. We used prescribed and spatially uniform vegetation and soil parameters. In the future, we will use a fully coupled atmosphere-ocean-land biosphere model to predict climate/vegetation feedbacks that are known to be important for past climate changes and variability. For example, a replacement of tundra with boreal forest could lead to additional climate warming, i.e., a positive feedback, because of the albedo difference in spring and between snow covered forest and snow covered tundra [Kutzbach et al., 1996; Ganopolski et al., 1998].

[51] Uncertainties remain concerning the inadequate representation of the water-vapor feedback mechanism in energy balance models [Pierrehumbert, 1995; Bates, 1999], which might alter our results as well as those from previous studies significantly. Also, consideration of Permian to modern changes in the aerosol loading might be relevant for the radiative budget, but there are no estimates of these properties available so far. The solutions of the simulations with the coupled atmospheric energy balance ocean general circulation model could result in multiple steady states [Mikolajewicz and Crowley, 1997]. However, we expect that the stability of our simulations is robust because of the asymmetry of the geography of Pangea with respect to the equator. Preliminary results from simulations with a transient $\mathrm{CO}_{2}$ radiative forcing 2 two times $\mathrm{CO}^{2}$ to one times $\mathrm{CO}_{2}$ support these findings.

[52] Paleogeographic and topographic reconstruction of islands is still uncertain. For example, we deduce from our experiments and comparison with those of Kutzbach et al. [1990] that a more southward position of South China would imply a higher heat transport into the Tethys Sea and a warming of the adjacent coasts. The bathymetry and the details of polar seaways are also uncertain. The outcome of this study will be helpful for the design of future fully coupled climate studies, in particular with respect to changes in the land-sea distribution, greenhouse gas radiative forcing, and changes in the orbital configuration. In addition, a coupling of these climate models to a marine biogeochemical model would give a more detailed insight concerning possible anoxic conditions in the Panthalassa 
ocean that might have implications for the Late Permian mass extinction.

[53] Acknowledgments. We thank Cornelia Winguth for reading this manuscript, David Archer for fruitful discussions and Pat Behling for setting up and running the GENESIS 2 climate model experiments and for providing the forcing fields from the GENESIS run of Gibbs et al. [2002] for the LSG ocean model. We thank Matthew Huber and Lisa Sloan for many detailed comments which improved the quality of the manuscript. This work was done in collaboration with the Max-Planck-Institut für Meteorology, the Deutsche Forschungsgemeinschaft SPP 1054, and with the University of Chicago (supported by the Packard Foundation). John Kutzbach is supported by NSF grant ATM-9815980, and Arne Winguth by NASA grant NAG5-11245.

\section{References}

Bates, J. R., A dynamical stabilizer in the climate system: A mechanism suggested by a simple model, Tellus, Ser. A, 51, 349-372, 1999.

Barron, E. J., and P. J. Fawcett, The climate of Pangaea: A review of climate model simulations of the Permian, in The Permian of Northern Pangaea, vol. 1, Paleogeography, Paleoclimates, Stratigraphy, edited by P. A. Scholle, T. M. Peryt, and D. S. Ulmer-Scholle, pp. 37-52, Springer-Verlag, New York, 1995.

Berger, A. L., Long-term variation of calcoric insolation resulting from the Earth's orbital elements, Quat. Res., 9, 139-167, 1978.

Berner, R. A., GEOCARBII: A revised model of atmospheric $\mathrm{CO}_{2}$ over Phanerozoic time, $\mathrm{Am}$. J. Sci., 294, 56-91, 1994.

Berner, R. A., The rise of plants and their effect on weathering and atmospheric $\mathrm{CO}_{2}$, Science, 276, 544-546, 1997.

Bice, K., An investigation of early Eocene deep water warmth using uncoupled atmosphere and ocean general circulation models: Model sensitivity to geography, initial temperatures, atmospheric forcing and continental runoff, Ph.D. thesis, 363 pp., Pa. State Univ., University Park, 1997.

Caldeira, K., and J. F. Kasting, The life span of the biosphere revised, Nature, 360, 721-723, 1992.

Crowley, T. J., and S. K. Baum, Modeling late Paleozoic glaciation, Geology, 20, 507-510, 1992.

Crowley, T. J., and S. K. Baum, Reconciling late Ordovician (440 Ma) glaciation with very high (14X) $\mathrm{CO}_{2}$ levels, J. Geophys. Res., 100, $1093-1101,1995$

Crowley, T. J., and G. R. North (Eds.), Paleoclimatology, 339 pp., Oxford Univ. Press, New York, 1991.

Crowley, T. J., S. K. Baum, and W. T. Hyde, Milankovitch fluctuations on supercontinents, Geophys. Res. Lett., 19, 793-796, 1992.

Cubasch, U., et al., Projections of future change, in Climate Change 2001: The Scientific Basis, Contribution of Working Group I to the Third Assessment report of the Intergovernmental Panel on Climate Change, edited by J. T. Houghton et al., pp. 525-582, Cambridge Univ. Press, New York, 2001.

DeConto, R. M., W. W. Hay, S. L. Thompson, and J. C. Bergengren, Late Cretaceous climate and vegetation interactions: The cold continental interior paradox, in The Evolution of Cretaceous Ocean/Climate Systems, edited by E. Barrera and C. Johnson, Spec. Pap. Geol. Soc. Am., 332, 391-406, 1999.

Dorman, G. J., and P. J. Sellers, A global climatology of albedo, roughness length and stomatal resistance for atmospheric general models as represented by the simple biosphere model (SiB), J. Appl. Meteorol., 28, 833-855, 1989.

Dutton, J. F., and E. J. Barron, Miocene to present vegetation changes, a possible piece of the Cenozoic puzzle, Geology, 25, 39-41, 1997.

Fawcett, P. J., Simulation of climate-sedimentary evolution: A comparison of climate model re- sults with the geologic record for India and Australia, Ph.D. thesis, 327 pp., Pa. State Univ., University Park, 1994.

Ganopolski, A., S. Rahmstorf, V. Petouhov, and M. Claussen, Simulation of modern and glacial climates with a coupled global model of intermediate complexity, Nature, 391, 351-356, 1998

Gibbs, M. T., P. M. Rees, J. E. Kutzbach, A. M Ziegler, P. J. Behling, and D. B. Rowley, Simulation of Permian climate and comparison with climate-sensitive sediments, J. Geol., 110, $33-55,2002$.

Hansen, J., I. Fung, A. Lacis, D. Rind, S. Lebedeff, R. Ruedy, and G. Russel, Global climate changes as forecast by the GISS's three-dimensional model, J. Geophys. Res., 93, $9341-$ 9364, 1988.

Hulver, M. L., A. M. Ziegler, D. R. Rowley, and M. T. Gibbs, Global latitudinal distribution of Permian to Recent climate-sensitive sediments, Geol. Soc. Am. Abstr. Programs, 29, 6, 1997.

Isozaki, Y., Permo-Triassic boundary superanoxia and stratified superocean: Records from lost deep sea, Science, 276, 235-238, 1997

Kutzbach, J. E., and A. M. Ziegler, Simulation of late Permian climate and biomes with an atmosphere/ocean model: Comparisons with observations, in Palaeoclimates and Their Modelling with Special Reference to the Mesozoic Era, Philos. Trans. R. Soc. London, Ser. B, 341, 327-340, 1993.

Kutzbach, J. E., P. J. Guetter, and W. M. Washington, Simulated circulation of an idealized ocean for Pangaean time, Paleoceanography, 5, 299-317, 1990 .

Kutzbach, J. E., P. J. Bartlein, J. A. Foley, S. P. Harrison, S. Hostetler, Z. Liu, I. C. Prentice, and T. Webb III, Potential role of vegetation feedback in the climate sensitivity of high-latitude regions: A case study at 6000 years B.P., Global Biogeochem. Cycles, 10(4), 727-736, 1996

Lottes, A. L., and A. M. Ziegler, World peat distribution and the seasonality of climate and vegetation, Palaeogeogr. Palaeoclimatol. Palaeoecol., 106, 23-37, 1994.

Maier-Reimer, E., U. Mikolajewicz, and K. Has selmann, Mean circulation of the Hamburg LSG OGCM and its sensitivity to the thermohaline surface forcing, J. Phys. Oceanogr., 23, $731-757,1993$

Mikolajewicz, U., A meltwater induced collapse of the "conveyor belt" thermohaline circulation and its influence on the distribution of $\Delta^{14} \mathrm{C}$ and $\delta^{18} \mathrm{O}$ in the oceans, Rep. 189, Max-Planck-Inst. für Meteorol., Hamburg, Germany, 1996.

Mikolajewicz, U., and T. J. Crowley, Response of a coupled ocean/energy balance model to restricted flow through the Central American isthmus, Paleoceanography, 12, 429-441, 1997.

Mikolajewicz, U., and R. Voss, The role of the individual air-sea flux components in $\mathrm{CO}_{2}$-induced changes of the ocean's circulation and climate, Clim. Dyn., 16, 627-642, 2000.
North, G. R., J. G. Mengel, and D. A. Short, Simple energy balance model resolving the seasons and the continents: Application to the astronomical theory of the ice ages, J. Geophys. Res., 88, 6576-6586, 1983.

Oort, A. H., and J. P. Peixoto, Global angular momentum and energy balance requirements from observations, Adv. Geophys., 25, 355490, 1983

Otto-Bliesner, B. L., Tropical mountains and coal formation: A climate model study of the Westphalian (306 Ma), Geophys. Res. Lett., 20, 1947-1950, 1993

Otto-Bliesner, B. L., Effects of tropical mountain elevations on the climate of the Late Carboniferous: Climate model simulations, in Tectonic Boundary Conditions for Climate Reconstructions, edited by T. J. Crowley and K. C. Burke, pp. 100-115, Oxford Univ. Press, New York, 1998.

Parish, J. T., (Ed.), Pre-Quaternary Climate From the Geologic Record, Columbia Univ. Press, New York, 338 pp., 1998.

Pierrehumbert, R. T., Thermostats, radiator fins, and the local runaway Greenhouse, J. Atmos. Sci., 52(10), 1784-1806, 1995.

Poussard, P. F., A. J. Weaver, and C. R. Barnes, Late Ordovician glaciation under high atmospheric $\mathrm{CO}_{2}$ : A coupled model analysis, $\mathrm{Pa}$ leoceanography, 14, 542-558, 1999.

Ramaswamy, V., et al., Radiative forcing of climate change, in Climate Change 2001: The Scientific Basis, Contribution of Working Group I to the Third Assessment Report of the Intergovernmental Panel on Climate Change, edited by J. T. Houghton et al., pp. 350-416, Cambridge Univ. Press, New York, 2001.

Rees, P. M., M. T. Gibbs, A. M. Ziegler, J. E. Kutzbach, and P. J. Behling, Permian climates: Evaluating model predictions using global paleobotanical data, Geology, 27, 891-894, 1999.

Rees, P. M., A. M. Ziegler, M. T. Gibbs, J. E. Kutzbach, P. J. Behling, and D. B. Rowley, Permian phytogeographic patterns and climate data-model comparisons, J. Geol., 110, 1-31, 2002.

Schiller, A., U. Mikolajewicz, and R. Voss, The stability of the North Atlantic thermohaline circulation in a coupled ocean-atmosphere general circulation model, Clim. Dyn., 13 325-347, 1997

Scrutton, C. T., Periodic growth features in fossil organisms and the length of the day and the month, in Tidal Friction and the Earth Rotation, edited by P. Brosche and J. Suendermann, pp. 154-196, Springer-Verlag, New York, 1978.

Seyfert, C. K., and L. A. Sirkin, Earth History and Plate Tectonics, 2nd ed., 600 pp., Harper and Row, New York, 1979.

Sepkoski, J., Jr., Patterns of Phanerozoic extinction: A perspective from global data bases, in Global Events and Event Stratigraphy in the Phanerozoic, edited by O. H. Walliser, pp 36-51, Springer-Verlag, New York, 1995 
Shin, S.-I., Understanding the climate of the Last Glacial Maximum using a climate system model, Ph.D. thesis, 169 pp., Univ. of Wis.Madison, Madison, 2002.

Stommel, H., and A. B. Arons, On the abyssal circulation of the world ocean, II, An idealized model of the circulation pattern and amplitude in oceanic basins, Deep Sea Res., 6, 217-233, 1960.

Thompson, S. L., and D. Pollard, Greenland and Antarctic mass balances for present and doubled atmospheric $\mathrm{CO}_{2}$ from GENESIS version 2 global climate model, J. Clim., 10, 871-900, 1997.

Wigley, T. M. L., Relative contributions of different trace gases to the greenhouse effect, Clim. Monit., 16, 14-29, 1987.

Williams, D. M., J. Harkin, and A. H. N. Rice, Umbers, ocean crust and the Irish Caledonides:
Terrane transpression and the morphology of the Laurentian margin, J. Geol. Soc. London, 154, 829-838, 1997.

Ziegler, A. M., Warm polar currents, Eos Trans. $A G U, 78(17)$, Spring Meet. Suppl., S50, 1998.

Ziegler, A. M., C. R. Scotese, W. S. McKerrow, M. E. Johnson, and R. K. Bambach, Paleozoic paleogeography, Annu. Rev. Earth Planet. Sci., 7, 502-743, 1979.

Ziegler, A. M., M. L. Hulver, A. L. Lottes, and W. F. Schmactenberg, Uniformitarianism and palaeoclimates: Inferences from the distribution of carbonate rocks, in Fossils and Climate, edited by P. J. Brenchley, pp. 3-25, John Wiley, New York, 1984.

Ziegler, A. M., M. L. Hulver, and D. B. Rowley, Permian world topography and climate, in Late Glacial and Postglacial Environmental Changes-Quaternary, edited by I. P. Martini, pp. 111-146, Oxford Univ. Press, New York 1997.

Ziegler, A. M., M. T. Gibbs, and M. L. Hulver, A mini-atlas of oceanic water masses in the Permian period, Proc. R. Soc. Aust., 110(1/2), 323-343, 1998.

C. Heinze, E. Maier-Reimer, and U. Mikolajewicz, Max-Planck-Institut für Meteorologie, 20146 Hamburg, Germany.

J. E. Kutzbach and A. M. E. Winguth, Center for Climatic Research, University of WisconsinMadison, Madison, WI 53710, USA. (amwinguth @)facstaff.wisc.edu)

A. Rees, D. Rowley, and A. M. Ziegler, Department of Geophysical Sciences, University of Chicago, Chicago, IL 60637, USA. 
a)

WORDIAN (267-264 MA)

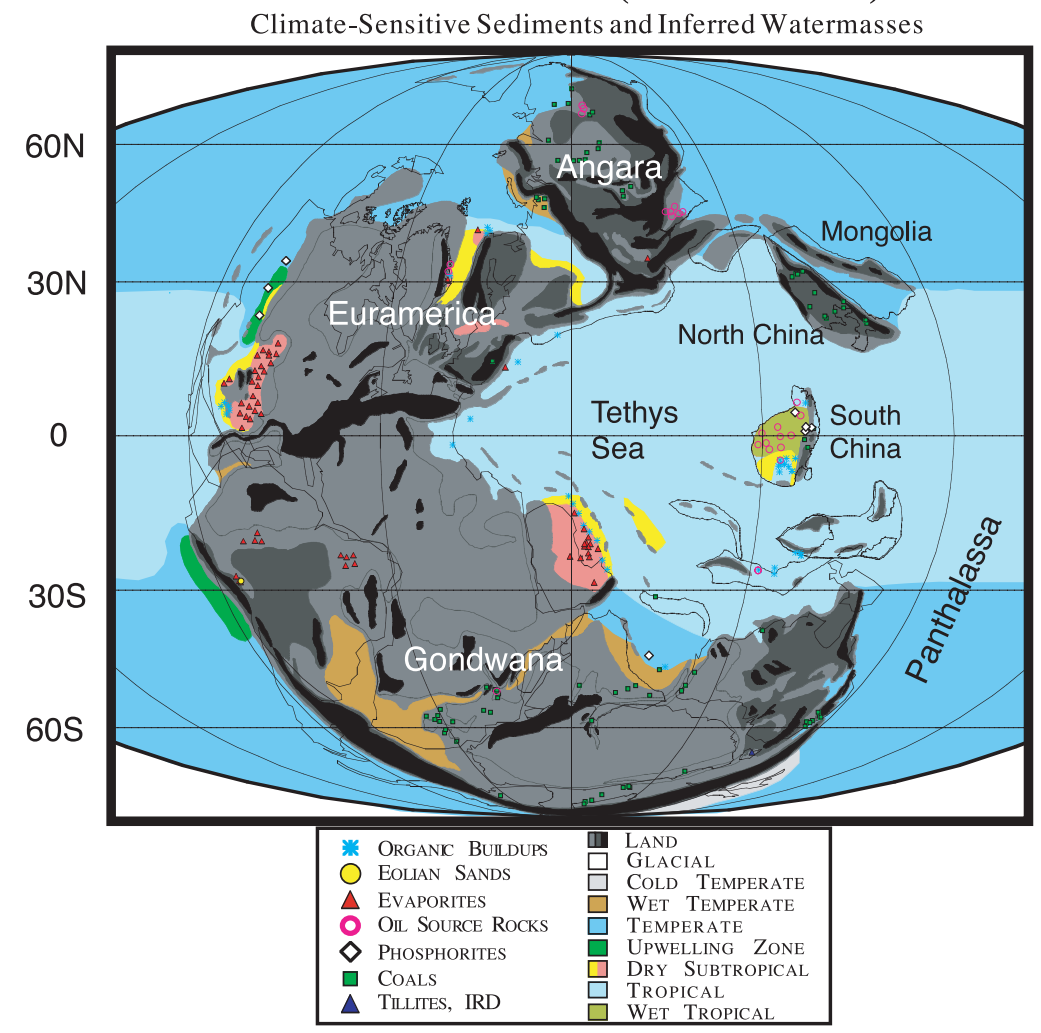

b)

\section{MODEL SIMULATION (4xCO2)}

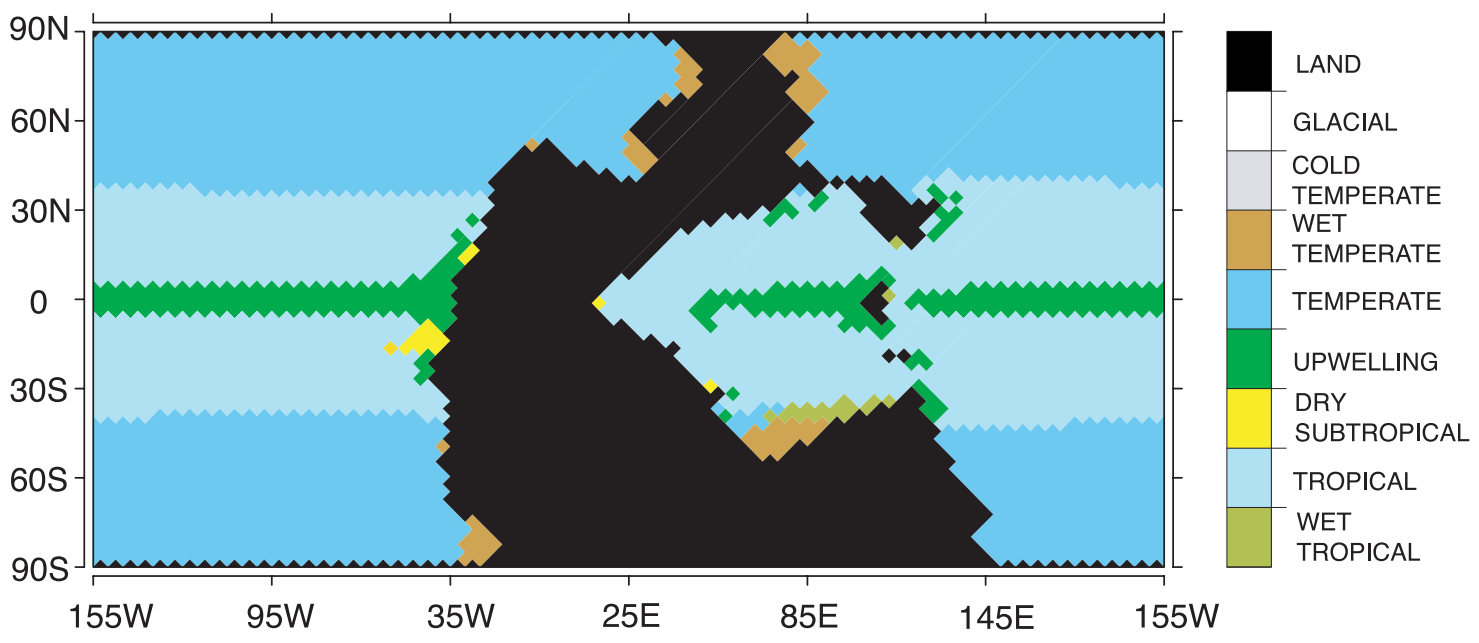

Figure 13. (a) Wordian (Kazanian, early Maokouan) climate sensitive sediments and reconstructed water masses from Ziegler et al. [1998]. (b) Water mass classification derived from the climate simulation with $4 \times \mathrm{CO}_{2}$ using the classification scheme of Table 2 . 